Article

\title{
Evaluation of CFOSAT Scatterometer Wind Data in Global Oceans
}

\author{
Haijun Ye ${ }^{1,2}$, Junmin Li ${ }^{1,2} \mathbb{D}$, Bo Li ${ }^{1,2}$, Junliang Liu 1,2, Danling Tang ${ }^{2}$, Wuyang Chen ${ }^{1,2}$, Hongqiang Yang ${ }^{3}$, \\ Fenghua Zhou ${ }^{1,2}$, Rongwang Zhang ${ }^{1,2} \mathbb{D}$, Sufen Wang ${ }^{1,2}$ and Shilin Tang ${ }^{1,2, *}$ \\ 1 State Key Laboratory of Tropical Oceanography, Guangdong Key Laboratory of Ocean Remote Sensing, \\ South China Sea Institute of Oceanology, Chinese Academy of Sciences, Guangzhou 510301, China; \\ yehaijun@scsio.ac.cn (H.Y.); jli@scsio.ac.cn (J.L.); libo@scsio.ac.cn (B.L.); lerry710@scsio.ac.cn (J.L.); \\ chenwuyang@scsio.ac.cn (W.C.); zhoufh@scsio.ac.cn (F.Z.); rwzhang@scsio.ac.cn (R.Z.); \\ sufenwang@scsio.ac.cn (S.W.) \\ 2 Southern Marine Science and Engineering Guangdong Laboratory (Guangzhou), Guangzhou 511458, China; \\ lingzistdl@126.com \\ 3 CAS Key Laboratory of Ocean and Marginal Sea Geology, South China Sea Institute of Oceanology, \\ Chinese Academy of Sciences, Guangzhou 510301, China; hqyang@scsio.ac.cn \\ * Correspondence: sltang@scsio.ac.cn
}

Citation: Ye, H.; Li, J.; Li, B.; Liu, J.; Tang, D.; Chen, W.; Yang, H.; Zhou, F.; Zhang, R.; Wang, S.; et al. Evaluation of CFOSAT Scatterometer Wind Data in Global Oceans. Remote Sens. 2021, 13, 1926. https://doi.org/10.3390/ rs13101926

Academic Editors: Martin Gade and Sergey Stanichny

Received: 30 March 2021

Accepted: 10 May 2021

Published: 14 May 2021

Publisher's Note: MDPI stays neutral with regard to jurisdictional claims in published maps and institutional affiliations.

Copyright: (C) 2021 by the authors Licensee MDPI, Basel, Switzerland This article is an open access article distributed under the terms and conditions of the Creative Commons Attribution (CC BY) license (https:// creativecommons.org/licenses/by/ $4.0 /)$

\begin{abstract}
The China-France Oceanography SATellite (CFOSAT), launched on 29 October 2018, is a joint mission developed by China and France. To evaluate the CFOSAT wind product, L2B swath data with a spatial resolution of $25 \times 25 \mathrm{~km}$ were compared with in situ measurements between December 2018 and December 2020. The in situ measurements were collected from 217 buoys. All buoy winds were adjusted to $10 \mathrm{~m}$ height using a simple logarithmic correction method. The temporal and spatial separations between the CFOSAT and in situ measurements were restricted to less than $30 \mathrm{~min}$ and $0.25^{\circ}$. The results indicate that the CFOSAT wind retrievals agree well with the buoy measurements. The root mean square errors (RMSEs) of wind vectors were $1.39 \mathrm{~m} \mathrm{~s}^{-1}$ and $34.32^{\circ}$ and negligible biases were found. In the near shore under rain-free conditions, the RMSEs were enhanced to $1.42 \mathrm{~m} \mathrm{~s}^{-1}$ and $33.43^{\circ}$. Similarly, the RMSEs were reduced to $1.16 \mathrm{~m} \mathrm{~s}^{-1}$ and $30.41^{\circ}$ offshore after the rain effect was removed. After winds less than $4 \mathrm{~m} \mathrm{~s}^{-1}$ were removed, the RMSE of wind directions was reduced to $19.69^{\circ}$. The effects of significant wave height, air-sea temperature difference, sea surface temperature, atmospheric pressure and ocean surface current on the wind residuals were assessed. The performance of wind retrievals under the passage of tropical cyclones was evaluated. The evaluation results show that the CFOSAT wind retrievals satisfy the accuracy requirements of scientific research, although some improvements are needed to enhance the performance.
\end{abstract}

Keywords: CFOSAT; wind vector; evaluation; buoy; scatterometer

\section{Introduction}

Ocean surface wind vectors are fundamental parameters in various fields of meteorology, oceanography and climate studies [1]. Despite the importance of ocean surface wind data, there are few in situ wind data available in many areas of the ocean and most of the data are concentrated in coastal waters or near islands. Satellite observations have the advantages of covering a wide area simultaneously and regularly with a width of from $1000 \mathrm{~km}$ Advanced Scatterometer, (ASCAT), two swaths of approximately $500 \mathrm{~km}$ ) to $1800 \mathrm{~km}$ Quick Scatterometer, (QuikSCAT) and over a period of years. However, satellites do not measure wind vectors directly but, rather, measure radiation signals from the sea surface. Therefore, it is necessary to characterize the overall accuracy and precision of China-France Oceanography SATellite (CFOSAT) wind retrievals before they can be used for meteorological, oceanic and climatic studies. 
Many studies have been conducted to compare scatterometer, radiometer and altimeter satellite wind retrievals with in situ measurements and numerical weather predictions (the European Center for Medium-Range Weather Forecasts (ECMWF)) and cross validation between different satellite retrievals has been performed to evaluate the quality of different satellite wind products. In particular, previous studies have evaluated the wind data for the Special Sensor Microwave Image (SSM/I) series [2,3], QuikSCAT [4-6], ASCAT [7], Haiyang-2A (HY-2A) [3,8,9], Haiyang 2B (HY-2B) [10,11], WindSat [12-15], Advanced Microwave Scanning Radiometer (AMSR) series [3], Sentinel [16] and Jason [16].

CFOSAT is a joint mission of China and France that was successfully launched on 29 October 2018. The primary scientific objective of CFOSAT is to monitor the global ocean surface wind vectors and sea wave spectrum. This ambitious objective is accomplished with two Ku-band payloads: the wind scatterometer (SCAT) supplied by the China National Space Administration and the wave scatterometer supplied by the Centre National d'Etudes Spatiales (CNES) of France. The SCAT is the first rotating fan-beam scatterometer with alternating horizontal and vertical polarizations. It measures the sea surface wind vector within a swath width of $1000 \mathrm{~km}$. The operational requirements (designed accuracy) of SCAT wind vectors are better than $2.0 \mathrm{~m} \mathrm{~s}^{-1}$ or $10 \%$ (larger) within $4-24 \mathrm{~m} \mathrm{~s}^{-1}$ and the wind direction is better than $\pm 20^{\circ}$.

After the launch of CFOSAT, three preliminary evaluation studies [17-19] reported that the CFOSAT wind vectors agree well with the ECMWF reanalysis data. Based on one-view data of the nominal working mode on 18 December 2018, Lin et al. [17] noted that CFOSAT wind speed is overestimated at low wind $\left(<4 \mathrm{~m} \mathrm{~s}^{-1}\right)$ and underestimated at high wind ( $\left.>15 \mathrm{~m} \mathrm{~s}^{-1}\right)$. According to several days of CFOSAT data, Zhu et al. [18] first reported that the biases of wind speed and wind direction between CFOSAT and ECMWF reanalysis data were $0.03 \mathrm{~m} \mathrm{~s}^{-1}$ and $0.39^{\circ}$ and the standard deviations (STDs) between them were $1.45 \mathrm{~m} \mathrm{~s}^{-1}$ and $14.28^{\circ}$, respectively. In the period of July 2019 to December 2019 over oceans at high latitudes $\left(>60^{\circ} \mathrm{N}\right)$, the STDs between CFOSAT and ECMWF reanalysis data and Oceabsat-2 Scatterometer (OSCAT2) and ASCAT-B were $1.29 \mathrm{~m} \mathrm{~s}^{-1}, 0.98 \mathrm{~m} \mathrm{~s}^{-1}$ and $0.87 \mathrm{~m} \mathrm{~s}^{-1}$, respectively [19]. However, CFOSAT wind vectors have not yet been evaluated over the global ocean using in situ measurements. In the present study, CFOSAT wind vectors are compared with near shore and offshore in situ buoy measurements to evaluate the performance of CFOSAT wind retrievals.

\section{Materials and Methods}

\subsection{CFOSAT SCAT Wind Data}

CFOSAT is a sun-synchronous satellite with a $520 \mathrm{~km}$ orbital altitude and an inclination angle of $97.4^{\circ}$ and its repeat cycle is 13 days. The design lifetime of the CFOSAT satellite is 3 years. The SCAT is a rotating fan-beam radar with large incidence angles $\left(28-51^{\circ}\right)$ and a working frequency of $13.256 \mathrm{GHz}$ [17]. The CFOSAT wind data were inverted based on an National Aeronautics and Space Administration Scatterometer (NSCAT)-4 geophysical model function by using the maximum likelihood estimation and the inversion residual was used as the wind quality indicator [17,20]. A 2-D variational method was applied to remove the wind ambiguities [20]. To date, the CFOSAT team has published L2 data products with spatial resolutions of $12.5 \times 12.5 \mathrm{~km}$ and $25 \times 25 \mathrm{~km}$ for scientific research.

As swath products with a $12.5 \mathrm{~km}$ resolution are available only after September 2019, to obtain more collocations, L2B swath data with a spatial resolution of $25 \times 25 \mathrm{~km}$ were used to evaluate the quality of the CFOSAT wind product. All swath data are freely available at the China Ocean Satellite Data Service Center (https: / / osdds.nsoas.org.cn/, 1 March 2021) and from AVISO (www.aviso.altimetry.fr/, 1 March 2021). In addition to the wind speeds and directions, L2B swath data contain times, positions and qualities. The quality includes flags of detected rain, land, large wind, small wind, ice, etc. In the present study, rain flags were used to divide the collocations into rainy and rain-free parts to evaluate the effects of rain on wind retrievals. 


\subsection{Buoy Datasets}

Buoy observations have been commonly used to evaluate the performance of satellite wind vectors. In this study, the performance of the CFOSAT wind product was evaluated using data from 217 buoys (Figure 1). One buoy from the National Earth System Science Data Center, National Science \& Technology Infrastructure of China (http:/ / www.geodata. cn, 1 January 2020), is located in the South China Sea. Five buoys from the National Marine Data Center (http:/ / mds.nmdis.org.cn/, 1 January 2020) are located on the east coast of China. Fifty-seven buoys operated by the Tropical Atmosphere Ocean (TAO) project are in the tropical Pacific Ocean. Thirteen buoys operated by the Pilot Research Moored Array (PIRATA) are in the tropical Atlantic Ocean. Sixteen buoys are operated by the Research Moored Array for African-Asian-Australian Monsoon Analysis and Prediction (RAMA) and are mainly located in the tropical Indian Ocean. Two buoys from the Ocean Climate Station are located in the mid-latitudes of the Pacific Ocean. A total of 123 buoys are operated by the National Data Buoy Center (NDBC), USA.

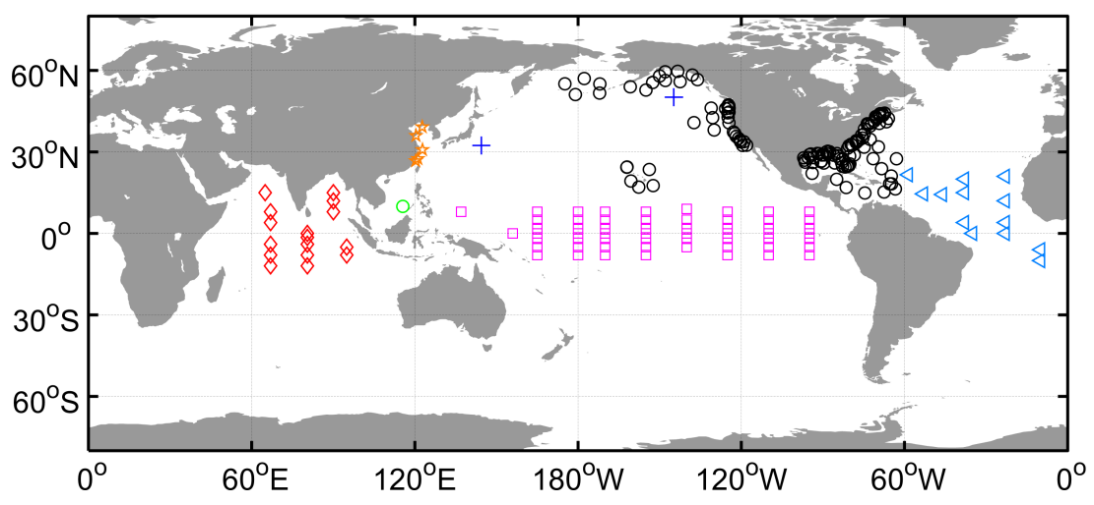

Figure 1. The locations of the 217 buoys used to evaluate the China-France Oceanography SATellite (CFOSAT) wind retrievals. Black circles, National Data Buoy Center (NDBC); pink squares, Tropical Atmosphere Ocean (TAO); red diamonds, Research Moored Array for African-Asian-Australian Monsoon Analysis and Prediction (RAMA); light blue left triangles, Pilot Research Moored Array (PIRATA); orange stars, the National Marine Data Center; green circle, the National Earth System Science Data Center; dark blue crosses, the Ocean Climate Station.

In addition to wind vectors, buoys also provide other information, such as the significant wave height (SWH), air temperature, sea surface temperature (SST), atmospheric pressure and ocean current vectors. All buoy data were first subjected to strict quality control. For example, records with warning flags or bar quality labels were removed. Outliers beyond reasonable physical variation ranges (e.g., $0-60 \mathrm{~m} \mathrm{~s}^{-1}$ for surface wind, $0-40{ }^{\circ} \mathrm{C}$ for air temperature and $-4-33^{\circ} \mathrm{C}$ for SST) were removed [21]. Records that had differences greater than five times the STD from their adjacent records were also removed to provide better data quality for the subsequent analyses. Among all 217 buoys, 81 are located near shore ( $<100 \mathrm{~km}$ from the shore) and 136 are located offshore (more than $100 \mathrm{~km}$ away from the shore and at water depths $>50 \mathrm{~m}$ ). The spatial distribution of all buoys is shown in Figure 1.

The CFOSAT wind products are tantamount to neutral winds at $10 \mathrm{~m}$ above the sea surface, while the buoy winds are measured at different heights. To make the buoy data comparable to the CFOSAT wind data, the buoy winds must be adjusted to neutral winds at a height of $10 \mathrm{~m}$. The direction of the wind is assumed not to change with the adjustment.

Several simple logarithmic and sophisticated algorithms have been frequently used to adjust the heights of buoy winds [2,22]. For sophisticated algorithms, several parameters, such as SST, air temperature, air pressure and relative humidity, are required. Most of these parameters are absent in most buoys. Previous findings have confirmed that the average deviation between the wind speeds adjusted by the sophisticated and simple logarithmic methods is approximately $0.1-0.12 \mathrm{~m} \mathrm{~s}^{-1}$, with an STD of $0.17 \mathrm{~m} \mathrm{~s}^{-1}[2,23]$. Therefore, a 
simple logarithmic method was used to adjust the buoy winds to neutral winds at a height of $10 \mathrm{~m}$ :

$$
\mathrm{U}_{\mathrm{z}}=\ln \left(\mathrm{z} / \mathrm{z}_{0}\right) / \ln \left(\mathrm{z}_{\mathrm{m}} / \mathrm{z}_{0}\right) \times \mathrm{U}\left(\mathrm{z}_{\mathrm{m}}\right)
$$

where $U_{z}$ and $U\left(z_{m}\right)$ are the wind speeds at heights $z$ and $z_{m}$, respectively; $z_{0}$ is the roughness length offset to be $1.52 \times 10^{-4} \mathrm{~m} \mathrm{[24]}$; and $\mathrm{z}_{\mathrm{m}}$ is the measurement height.

\subsection{Methods}

Three frequently used methods were used to evaluate the CFOSAT wind product. The mean bias was calculated as Bias $=\frac{1}{n} \sum_{i=1}^{n}\left(\mathrm{X}_{\mathrm{CFOSAT}}-\mathrm{X}_{\text {buoy }}\right)$.

The root mean square error (RMSE) is given by RMSE $=\sqrt{\frac{1}{n} \sum_{i=1}^{n}\left(X_{C F O S A T}-X_{\text {buoy }}\right)^{2}}$.

The STD is given by STD $=\sqrt{\frac{1}{n} \sum_{i=1}^{n}\left(\mathrm{X}_{\mathrm{CFOSAT}}-\mathrm{X}_{\text {buoy }}-\text { bias }\right)^{2}}$ where $n$ represents the number of collocations, $X_{C F O S A T}$ is the sea surface wind speed or wind direction data of CFOSAT and $X_{\text {buoy }}$ is the buoy observation. Since the wind direction is continuous at 0 and $360^{\circ}$, it should be $X_{\text {buoy }}=X_{\text {buoy }}+360$ when $X_{C F O S A T}-X_{\text {buoy }}>180^{\circ}$ and $X_{\text {buoy }}=X_{\text {buoy }}$ -360 when $X_{\text {CFOSAT }}-X_{\text {buoy }}<180^{\circ}$.

To assess the accuracy of the CFOSAT retrievals, the CFOSAT wind data and buoy measurements were collocated in time and space. Many temporal and spatial differences have been used in satellite-buoy comparison studies (Table S1, see Supplementary Material). To compare with other satellite products, the frequently used criteria of $0.25^{\circ}$ and $30 \mathrm{~min}$ were used in this study. It has been demonstrated that time differences between $15 \mathrm{~min}$ and one hour do not generate significant changes in the statistics of wind speed comparison [25]. Using the above method, 298,871 and 263,722 matchups for wind speed and wind direction, respectively, were obtained between December 2018 and December 2020. The discrepancy in the collocation number of wind speed and direction is mainly due to the absence of wind direction data in the NDBC.

\section{Results}

\subsection{Overall Statistics}

The CFOSAT wind vectors were compared with buoy measurements over the global oceans (Figure 2). Overall, the wind speed and direction agreed well with in situ measurements, with linear regression coefficients $(r)$ of 0.89 and 0.95 , respectively (Table 1 ). CFOSAT retrievals slightly overestimated the wind speed by $0.06 \mathrm{~m} \mathrm{~s}^{-1}$, with an RMSE of $1.39 \mathrm{~m} \mathrm{~s}^{-1}$ (Figure 2a). A negligible bias was found for the wind direction, with an RMSE of $34.32^{\circ}$ (Figure $2 \mathrm{~b}$ ). The difference between the RMSE and STD was quite small due to large collocations. The obvious discrepancy between in situ and CFOSAT winds at wind speeds $<7 \mathrm{~m} \mathrm{~s}^{-1}$ (green arrow in Figure 2a) was due to rain contamination, which prompted us to analyze the collocations according to rain flags and distance to shore.
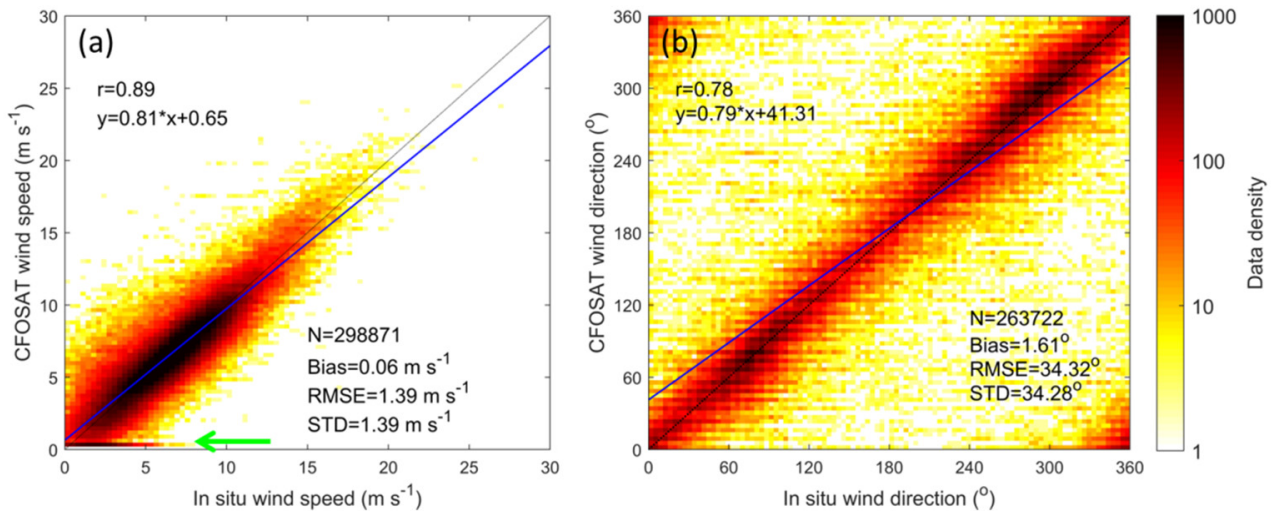

Figure 2. Scatter density plots of collocations for wind speeds (a) and directions (b). 
Table 1. The statistical parameters of wind speeds and directions between CFOSAT wind retrievals and in situ measurements under all weather, rain and rain-free conditions.

\begin{tabular}{|c|c|c|c|c|c|c|c|c|}
\hline & \multicolumn{2}{|c|}{ Bias } & \multicolumn{2}{|c|}{ Root Mean Square Error (RMSE) } & \multicolumn{2}{|c|}{$r$} & \multicolumn{2}{|c|}{ Collocations } \\
\hline & $\begin{array}{c}\text { Speed } \\
\left(\mathrm{m} \mathrm{s}^{-1}\right)\end{array}$ & $\begin{array}{c}\text { Direction } \\
\left({ }^{\circ}\right)\end{array}$ & $\begin{array}{c}\text { Speed } \\
\left(\mathrm{m} \mathrm{s}^{-1}\right)\end{array}$ & $\begin{array}{c}\text { Direction } \\
\left({ }^{\circ}\right)\end{array}$ & Speed & Direction & Speed & Direction \\
\hline All & 0.06 & 1.61 & 1.39 & 34.32 & 0.89 & 0.95 & 298,871 & 263,722 \\
\hline \multicolumn{9}{|c|}{ Near shore } \\
\hline All & 0.33 & 2.57 & 1.63 & 36.97 & 0.89 & 0.94 & 57,837 & 53,691 \\
\hline Rain & 0.53 & 2.16 & 2.33 & 49.27 & 0.86 & 0.9 & 11,187 & 10,218 \\
\hline No Rain & 0.28 & 2.67 & 1.42 & 33.43 & 0.91 & 0.95 & 46,650 & 43,473 \\
\hline \multicolumn{9}{|c|}{ Offshore } \\
\hline All & -0.01 & 1.36 & 1.32 & 33.61 & 0.89 & 0.95 & 241,034 & 210,031 \\
\hline Rain & 0.27 & 0.01 & 2.4 & 56.15 & 0.84 & 0.87 & 22,084 & 19,295 \\
\hline No Rain & -0.04 & 1.5 & 1.16 & 30.41 & 0.9 & 0.96 & 218,950 & 190,736 \\
\hline
\end{tabular}

In the near shore areas, the RMSEs and biases of wind speeds and directions increased to $1.63 \mathrm{~m} \mathrm{~s}^{-1}$ and $36.97^{\circ}$ and $0.33 \mathrm{~m} \mathrm{~s}^{-1}$ and $2.57^{\circ}$, respectively (Figure 3). Although the $r$ of wind speed did not drop, a smaller intercept of $0.76 \mathrm{~m} \mathrm{~s}^{-1}$ was obtained (Figure 3a). The $r$ of the wind direction decreased to 0.94 with a larger intercept of $3.17^{\circ}$ (Figure 3b). According to the rain flag, the near shore collocations were separated into rainy $(19 \%)$ and rain-free $(81 \%)$ parts. Under rainy conditions, the biases and RMSEs of wind speeds were enhanced to $0.53 \mathrm{~m} \mathrm{~s}^{-1}$ and $2.33 \mathrm{~m} \mathrm{~s}^{-1}$, respectively (Figure 3c). Correspondingly, $r$ slightly decreased to 0.86 , with a larger intercept of $1.11 \mathrm{~m} \mathrm{~s}^{-1}$. Although the bias of wind direction decreased to $2.16^{\circ}$ under rainy conditions, the RMSE suddenly increased to $49.27^{\circ}$ and $r$ decreased to 0.90 , with a larger intercept of $5.60^{\circ}$ (Figure 3d). After rain exclusion, the RMSE and bias of wind speeds decreased to $1.42 \mathrm{~m} \mathrm{~s}^{-1}$ and $0.28 \mathrm{~m} \mathrm{~s}^{-1}$ and $r$ increased to 0.91 (Figure 3e). Likewise, the RMSE of wind directions decreased to $33.43^{\circ}$ and $r$ increased to 0.95 (Figure 3f).
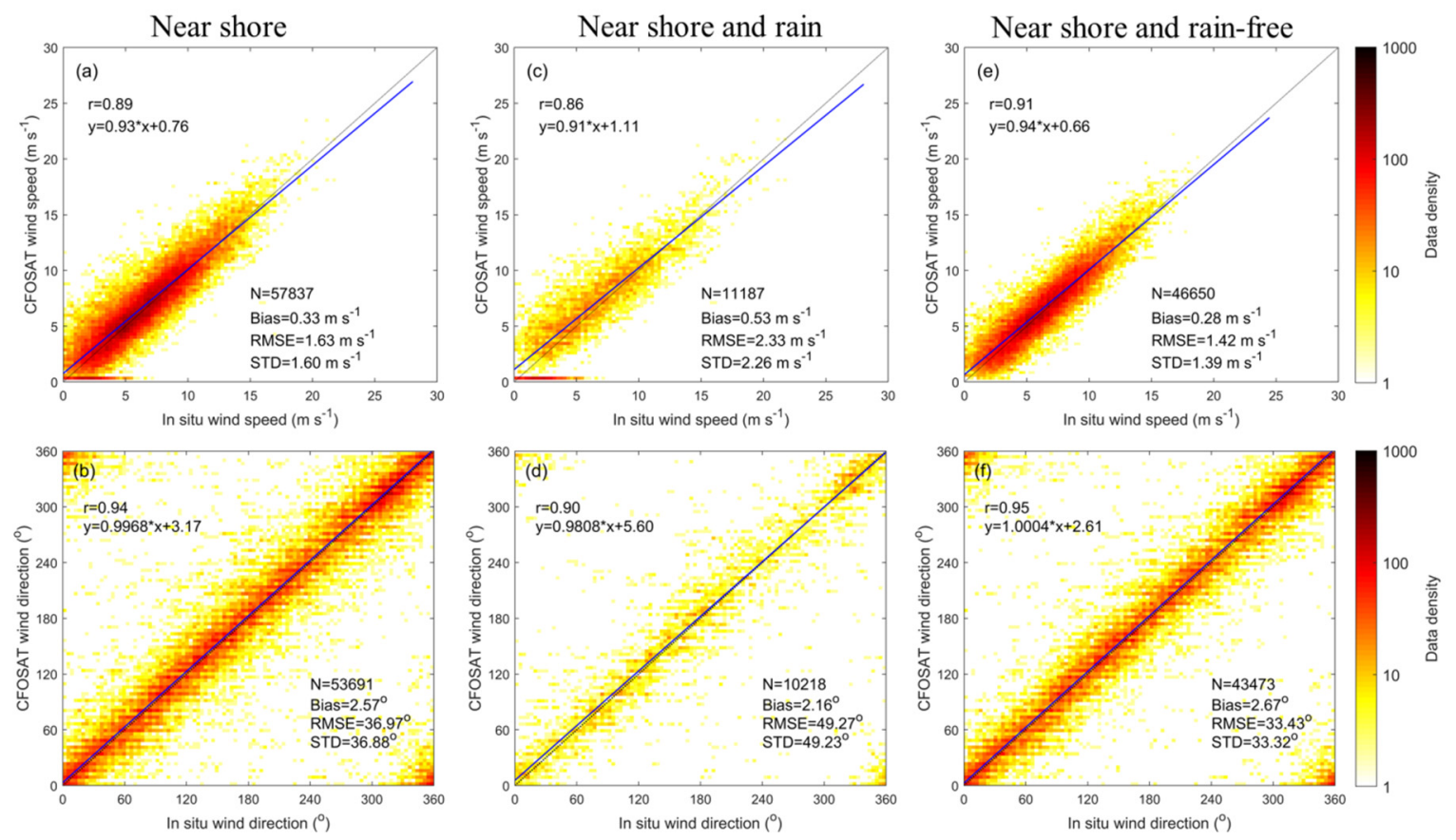

Figure 3. Scatter density plots of collocations for wind speeds (upper panels) and directions (lower panels) under all weather $(\mathbf{a}, \mathbf{b})$, rain $(\mathbf{c}, \mathbf{d})$ and rain-free $(\mathbf{e}, \mathbf{f})$ conditions in the near shore areas. 
In the offshore region, the RMSEs and biases of wind speeds dropped to $1.32 \mathrm{~m} \mathrm{~s}^{-1}$ and $-0.01 \mathrm{~m} \mathrm{~s}^{-1}$, respectively (Figure $4 \mathrm{a}$ ). The RMSEs and biases of wind directions dropped to $33.61^{\circ}$ and $1.36^{\circ}$, respectively (Figure 4b). Although the $r$ of wind speed and wind direction was not improved, smaller intercepts of $0.63 \mathrm{~m} \mathrm{~s}^{-1}$ and $0.67^{\circ}$ were obtained. Likewise, the offshore collocations were separated into rainy $(9 \%)$ and rain-free $(91 \%)$ parts using rain flags. Under rainy conditions, the bias and RMSE of wind speeds increased to $0.27 \mathrm{~m} \mathrm{~s}^{-1}$ and $2.40 \mathrm{~m} \mathrm{~s}^{-1}$, respectively, and $r$ decreased to 0.84 (Figure 4c). For the wind direction, a higher RMSE of $56.15^{\circ}$ and a lower $r$ of 0.87 were observed (Figure $4 \mathrm{~d}$ ). Under rain-free conditions, although the biases of wind speeds and directions slightly increased to $-0.04 \mathrm{~m} \mathrm{~s}^{-1}$ (Figure 4e) and $1.50^{\circ}$ (Figure 4f), the RMSEs decreased to $1.16 \mathrm{~m} \mathrm{~s}^{-1}$ and $30.41^{\circ}$ and $r$ improved to 0.90 and 0.96 , respectively.
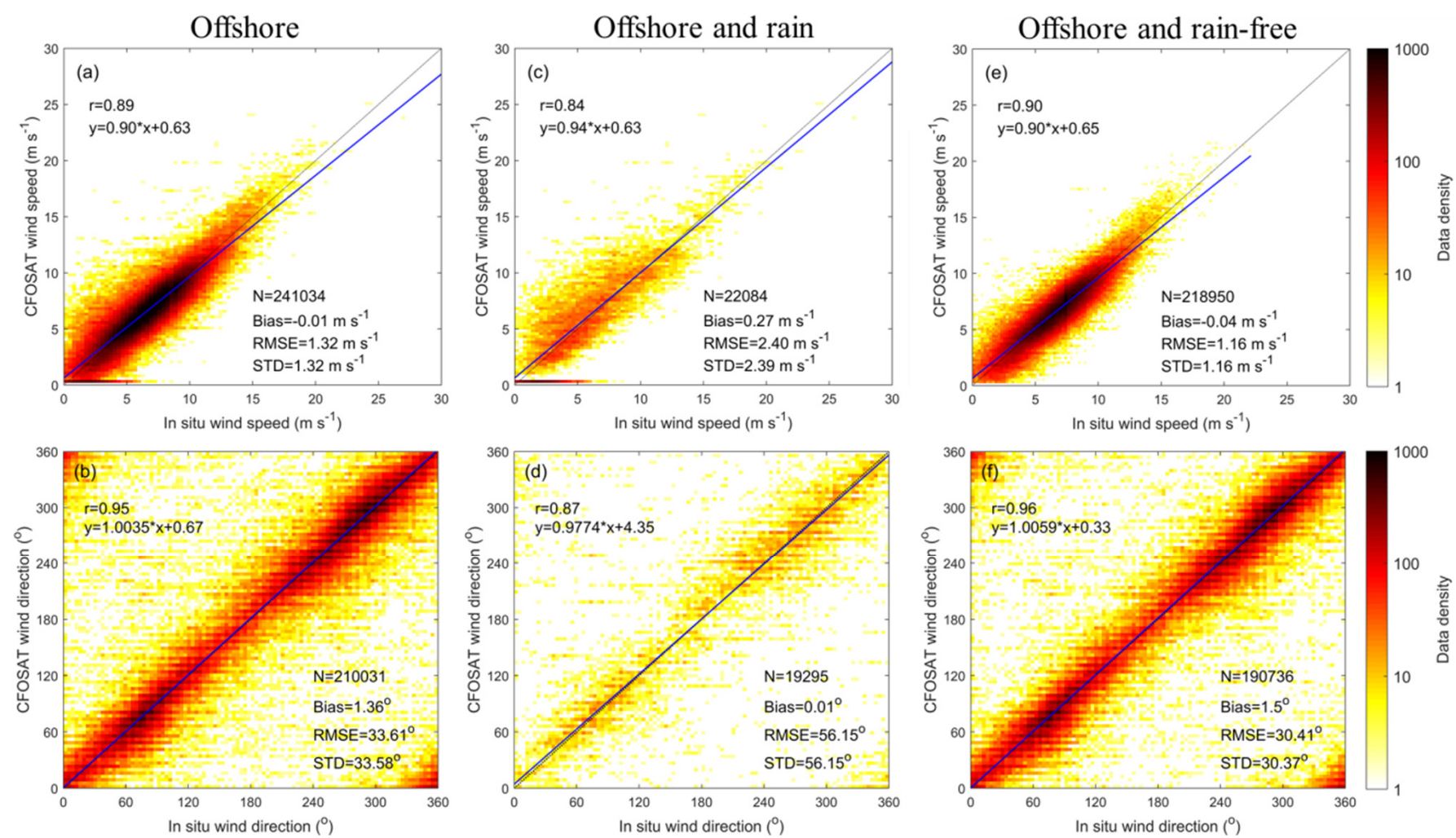

Figure 4. Scatter density plots of collocations for wind speeds (upper panels) and directions (lower panels) under all weather $(\mathbf{a}, \mathbf{b})$, rain $(\mathbf{c}, \mathbf{d})$ and rain-free $(\mathbf{e}, \mathbf{f})$ conditions in the offshore areas.

\subsection{Analysis of Residuals}

The residuals of wind vectors in $1 \mathrm{~m} \mathrm{~s}^{-1}$ bins of in situ wind speed under the conditions of all weather, rain-free and rain contamination in the offshore areas are presented in Figure 5. The wind speed biases gradually decreased from $1.28 \mathrm{~m} \mathrm{~s}^{-1}$ at wind speeds $<1 \mathrm{~m} \mathrm{~s}^{-1}$ to $-0.52 \mathrm{~m} \mathrm{~s}^{-1}$ in wind speed bins of $12 \mathrm{~m} \mathrm{~s}^{-1}$ and slightly increased to nearly zero at high winds (Figure 5a). Similarly, the RMSE decreased from $2.23 \mathrm{~m} \mathrm{~s}^{-1}$ to $1.07 \mathrm{~m} \mathrm{~s}^{-1}$ in wind speed bins $8 \mathrm{~m} \mathrm{~s}^{-1}$ and gradually increased to approximately $2 \mathrm{~m} \mathrm{~s}^{-1}$ at high winds. The bias of wind direction gradually linearly increased from $-3.34^{\circ}$ at low wind speeds to approximately $5^{\circ}$ at wind speeds $>15 \mathrm{~m} \mathrm{~s}^{-1}$ (Figure $5 \mathrm{~b}$ ). Similarly, the RMSE sharply decreased from $92.85^{\circ}$ to less than $20^{\circ}$ in wind speed bins of $7 \mathrm{~m} \mathrm{~s}^{-1}$ and gradually decreased to approximately $10^{\circ}$ at high winds. In brief, the accuracy of the CFOSAT wind speed generally first increased and then deceased, while the accuracy of the CFOSAT wind direction generally decreased with increasing wind speed. 

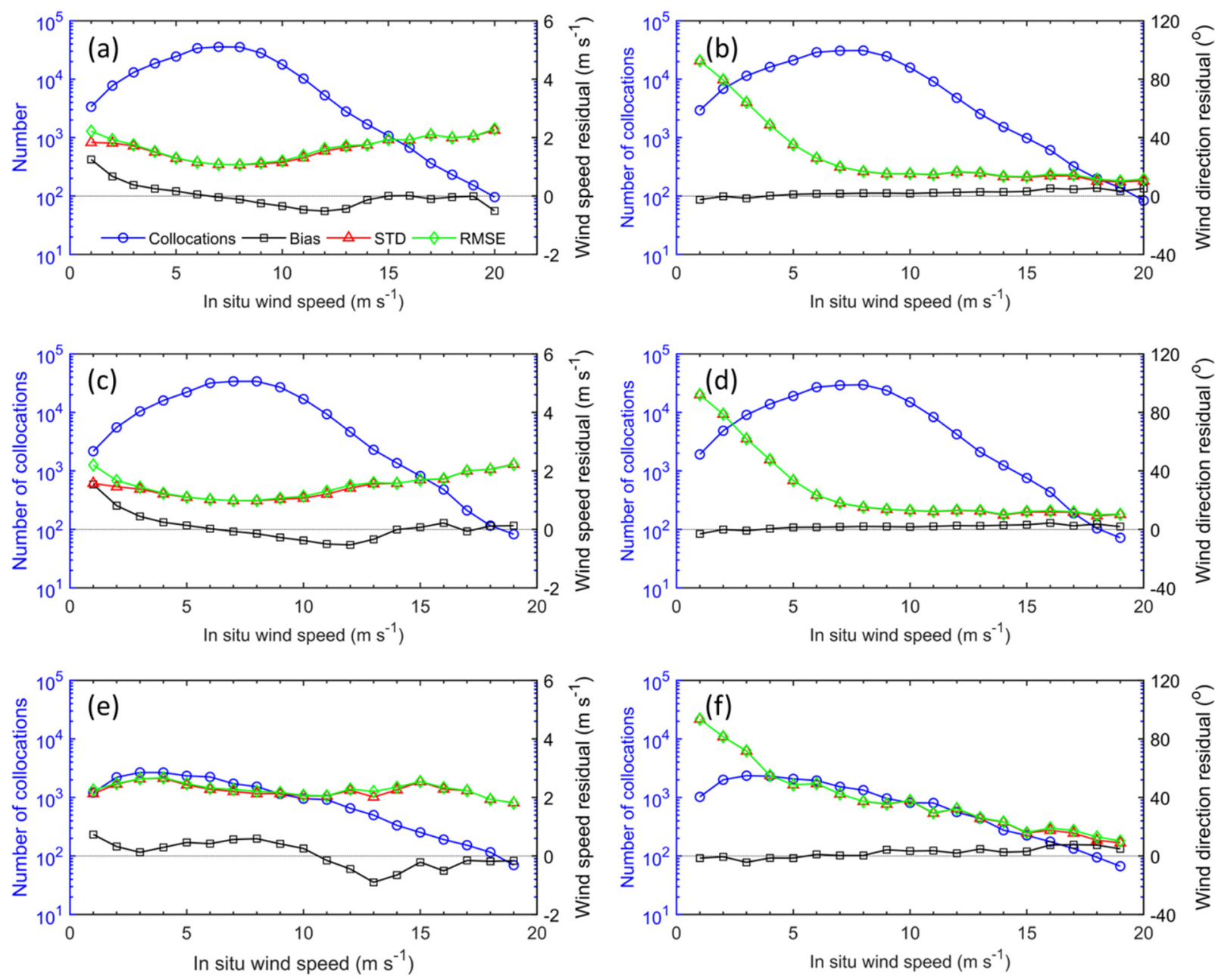

Figure 5. Residuals (CFOSAT_-in situ measurements) of wind speeds and directions calculated in $1 \mathrm{~m} \mathrm{~s}^{-1}$ bins of in situ wind speed under all weather $(\mathbf{a}, \mathbf{b})$, rain-free $(\mathbf{c}, \mathbf{d})$ and rain conditions $(\mathbf{e}, \mathbf{f})$ in the offshore areas. Blue circles, black squares, red triangles and green diamonds represent the number of collocations, bias, STD and RMSE, respectively. Only bins involving more than 50 collocations are plotted.

The accuracy was improved under rain-free conditions, except for a slightly higher bias at wind speeds $<3 \mathrm{~m} \mathrm{~s}^{-1}$ (Figure 5c). Specifically, the RMSE of wind directions dropped to $19.69^{\circ}$ and $15.11^{\circ}$ at wind speeds $>4 \mathrm{~m} \mathrm{~s}^{-1}$ and $>6 \mathrm{~m} \mathrm{~s}^{-1}$, respectively (Figure $5 \mathrm{~d}$ ). Under rainy conditions, a positive wind speed bias at wind speeds $<10 \mathrm{~m} \mathrm{~s}^{-1}$ and a negative bias at wind speeds $>10 \mathrm{~m} \mathrm{~s}^{-1}$ were observed and both the STD and RMSE were highly enhanced at wind speeds $<17 \mathrm{~m} \mathrm{~s}^{-1}$ (Figure 5e). Compared with that under rain-free conditions, a higher wind speed bias at wind speeds of $4-11 \mathrm{~m} \mathrm{~s}^{-1}$ and a lower bias at wind speeds $>12 \mathrm{~m} \mathrm{~s}^{-1}$ were obtained under rainy conditions. Both the RMSE and STD of the wind direction increased and the bias showed high variation (Figure $5 f$ ). In brief, rain significantly decreased the accuracy in both wind speed and direction.

\subsection{Errors Versus Buoy Location}

To better understand the performance of CFOSAT winds in different buoys, the geographic distribution of bias and RMSE under rain-free conditions in the offshore area were plotted, as shown in Figure 6. Each square or dot represents a buoy and the color of each symbol indicates the bias or RMSE between the CFOSAT wind retrievals and the matched in situ measurements. The positive wind speed bias is obvious in the Gulf of Mexico and at the $5^{\circ} \mathrm{N}-8^{\circ} \mathrm{N}$ and $8^{\circ} \mathrm{S}$ in the Pacific Ocean (Figure 6a). In contrast, the negative deviations are primarily located at $4^{\circ} \mathrm{N}-5^{\circ} \mathrm{S}$ in the Pacific Ocean, tropical Indian 
Ocean and Atlantic Ocean. The maximum bias of $0.73 \mathrm{~m} \mathrm{~s}^{-1}$ is located at $5^{\circ} \mathrm{N}, 155^{\circ} \mathrm{W}$ and the corresponding minimum bias of $-0.83 \mathrm{~m} \mathrm{~s}^{-1}$ is located at $0^{\circ} \mathrm{N}, 170^{\circ} \mathrm{W}$.
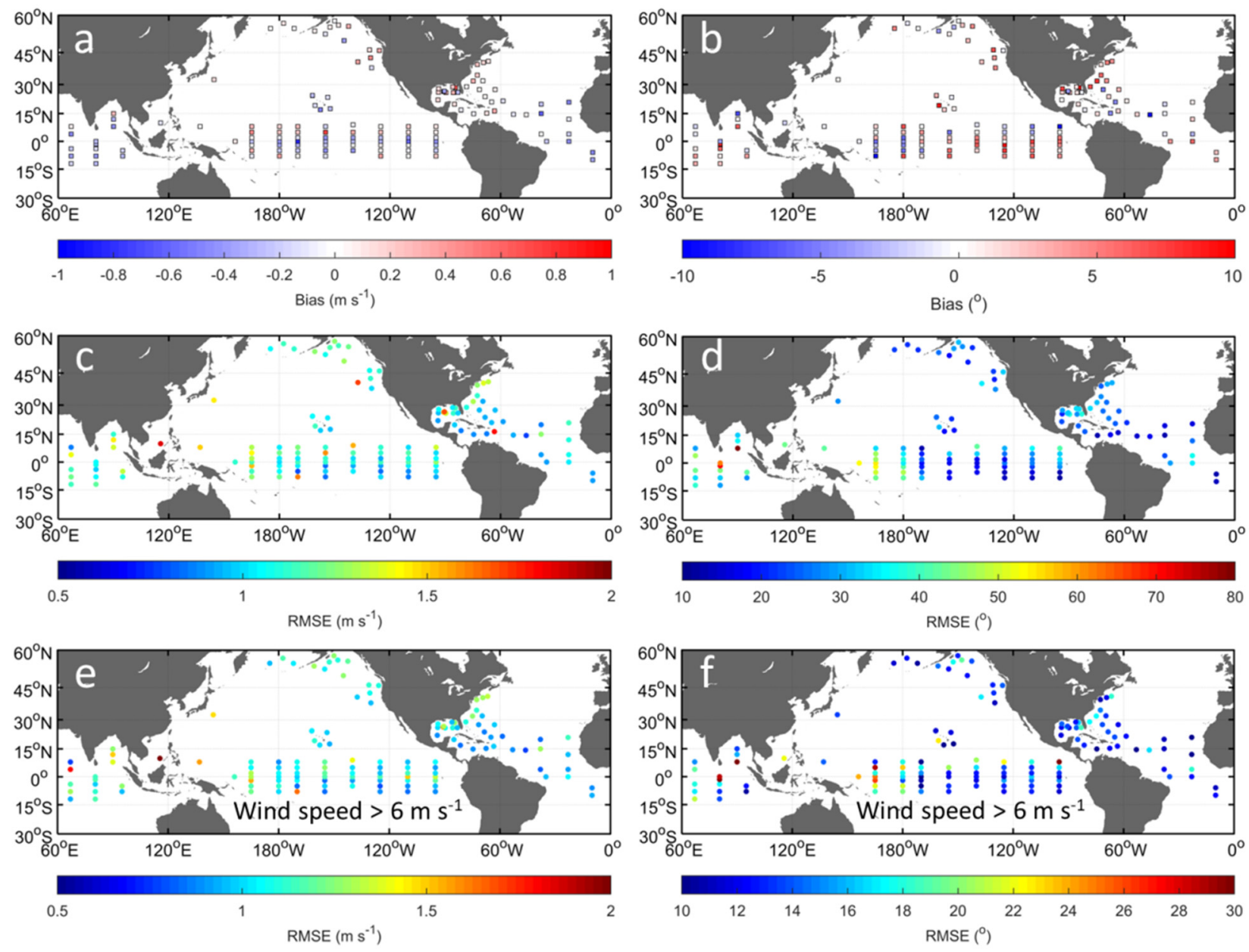

Figure 6. The mean difference $(\mathbf{a}, \mathbf{b})$ and RMSE $\left(\mathbf{c}-\mathbf{f}\right.$ (wind speed $>6 \mathrm{~m} \mathrm{~s}^{-1}$ )) of wind speeds and directions between CFOSAT and buoy at each buoy site offshore under rain-free conditions.

Figure $6 c$ represents the distribution of the RMSE of wind speed. Only 7 stations had RMSEs larger than $1.5 \mathrm{~m} \mathrm{~s}^{-1}$ and they were uniformly distributed in the global oceans. The maximum RMSE of approximately $1.84 \mathrm{~m} \mathrm{~s}^{-1}$ is located in the South China Sea. Low-RMSE buoys are primarily located in the South Pacific Ocean and tropical Atlantic Ocean. After wind speeds $<6 \mathrm{~m} \mathrm{~s}^{-1}$ were removed, the global distribution of wind speed RMSE did not change significantly (Figure 6e). The RMSE decreased only from $1.16 \mathrm{~m} \mathrm{~s}^{-1}$ to $1.11 \mathrm{~m} \mathrm{~s}^{-1}$.

For the wind direction, most buoys showed a positive bias in the Pacific Ocean and the Indian Ocean except for a few stations with negative biases of $5^{\circ} \mathrm{N}-8^{\circ} \mathrm{S}, 165^{\circ} \mathrm{E}-180^{\circ} \mathrm{W}$ and $5^{\circ} \mathrm{N}-8^{\circ} \mathrm{N}, 95^{\circ}-155^{\circ} \mathrm{W}$ (Figure $6 \mathrm{~b}$ ). The positive and negative biases were evenly distributed in the North Atlantic Ocean. The maximum bias was $9.96^{\circ}$, which is located at $2^{\circ} \mathrm{S}, 125^{\circ} \mathrm{W}$. The corresponding minimum bias was $-11.63^{\circ}$, which is located at $14.33^{\circ} \mathrm{N}$, $46.08^{\circ} \mathrm{W}$. It is clear that the RMSEs in the Atlantic Ocean and western tropical Pacific Ocean were smaller than those in the eastern tropical Pacific Ocean and Indian Ocean (Figure 6d). The maximum RMSE of $80.64^{\circ}$ is located at $8^{\circ} \mathrm{N}, 90^{\circ} \mathrm{E}$ and the minimum RMSE of $11.43^{\circ}$ is located at $8^{\circ} \mathrm{S}, 155^{\circ} \mathrm{W}$. In addition, some large RMSEs $>50^{\circ}$ occurred in the tropical Indian Ocean and western tropical Pacific Ocean. Similar to Figure 6e, the performance of wind direction RMSE significantly improved with the remove of wind speeds $<6 \mathrm{~m} \mathrm{~s}^{-1}$ (Figure 6f). Except for three buoys in the Pacific Ocean $\left(2^{\circ} \mathrm{S}, 165^{\circ} \mathrm{E} ; 5^{\circ} \mathrm{N}, 165^{\circ} \mathrm{E} ; 0^{\circ} \mathrm{N}\right.$, $\left.165^{\circ} \mathrm{E}\right)$ and four buoys in the Indian Ocean $\left(8^{\circ} \mathrm{N}, 90^{\circ} \mathrm{E} ; 8^{\circ} \mathrm{N}, 95^{\circ} \mathrm{W}, 1.5^{\circ} \mathrm{S}, 80.5^{\circ} \mathrm{E} ; 0^{\circ} \mathrm{N}\right.$, 
$80.5^{\circ} \mathrm{E}$ ), the RMSEs of the other buoys were less than $25^{\circ}$. One possible explanation is that there are some malfunctioning buoy instruments.

The distributions of the wind speed bias and RMSE under rain-free conditions the near shore region are shown in Figure 7. The overall results were worse than those of the offshore buoys, as shown in Table 2. The overall bias and RMSE on the coast of China were poorer than those on the US coast. The relatively high positive biases $\left(>2 \mathrm{~m} \mathrm{~s}^{-1}\right)$ are located near the coast of China. The bias of wind speeds near the coast of China was much larger than that near the coast of the US (Table 2). The wind speed RMSE range near the US coast is $0.93-2.61 \mathrm{~m} \mathrm{~s}^{-1}$ and that of the Chinese coast is $2.80-4.27 \mathrm{~m} \mathrm{~s}^{-1}$. The RMSE of wind speeds near the coast of China $\left(3.64 \mathrm{~m} \mathrm{~s}^{-1}\right)$ is approximately three times higher than that near the coast of the US $\left(1.38 \mathrm{~m} \mathrm{~s}^{-1}\right)$. After wind speeds $<6 \mathrm{~m} \mathrm{~s}^{-1}$ were removed, both biases and RMSEs near the China and US coasts decreased (Table 2).
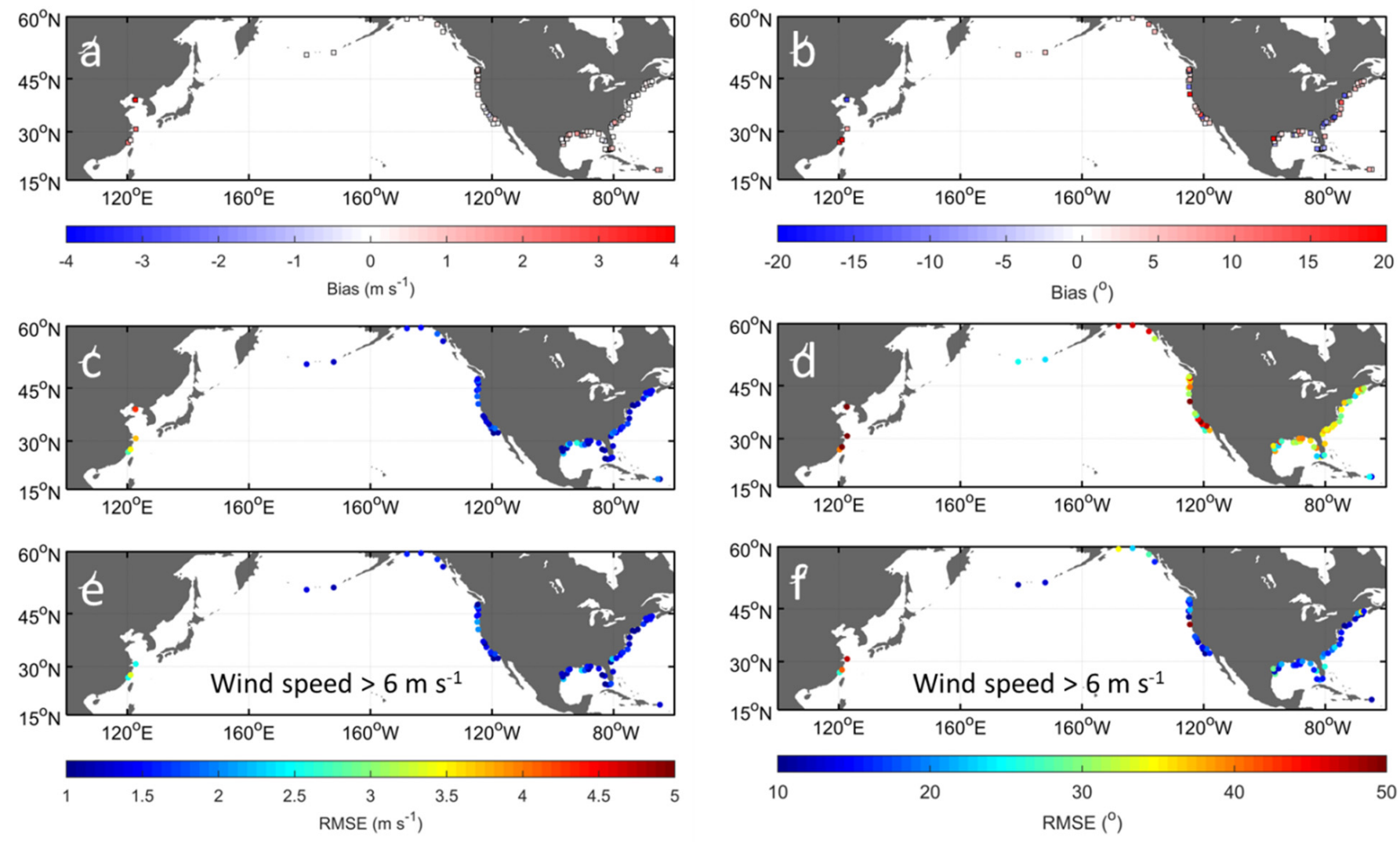

Figure 7. The mean difference $(\mathbf{a}, \mathbf{b})$ and RMSE $\left(\mathbf{c}-\mathbf{f}\right.$ (wind speed $\left.>6 \mathrm{~m} \mathrm{~s}^{-1}\right)$ ) of wind speeds and directions between CFOSAT and buoy at each buoy site in the near shore under rain-free conditions.

Table 2. The statistical parameters of wind speed and direction between CFOSAT wind retrievals and in situ measurements under rain-free conditions on the coasts of China and the US.

\begin{tabular}{|c|c|c|c|c|c|c|c|}
\hline \multirow[b]{2}{*}{ Coast } & \multicolumn{2}{|c|}{ Mean Bias } & \multicolumn{2}{|c|}{ RMSE } & \multirow{2}{*}{$\begin{array}{l}\text { Distance from } \\
\text { Shore }(\mathbf{k m})\end{array}$} & \multicolumn{2}{|c|}{ Collocations } \\
\hline & $\begin{array}{c}\text { Speed } \\
\left(\mathrm{m} \mathrm{s}^{-1}\right)\end{array}$ & $\begin{array}{c}\text { Direction } \\
\left({ }^{\circ}\right)\end{array}$ & $\begin{array}{c}\text { Speed } \\
\left(\mathrm{m} \mathrm{s}^{-1}\right)\end{array}$ & $\begin{array}{c}\text { Direction } \\
\left({ }^{\circ}\right)\end{array}$ & & Speed & Direction \\
\hline \multicolumn{8}{|c|}{ All wind speeds } \\
\hline China & 1.82 & 9.86 & 3.64 & 57.93 & $12.6 \pm 9.3$ & 410 & 409 \\
\hline US & 0.27 & 2.61 & 1.38 & 33.36 & $35.9 \pm 24.7$ & 45,258 & 42,082 \\
\hline \multicolumn{8}{|c|}{ Wind speeds $>6 \mathrm{~m} \mathrm{~s}^{-1}$} \\
\hline China & 0.14 & 7.02 & 2.95 & 41.18 & $13.9 \pm 10.3$ & 190 & 190 \\
\hline US & 0.15 & 2.62 & 1.37 & 16.75 & $37.3 \pm 24.5$ & 23,330 & 21,796 \\
\hline
\end{tabular}


The wind direction bias is negligible on the US coast and is approximately $10^{\circ}$ near the coast of China. Likewise, the RMSE of the wind direction near the coast of China $\left(57.93^{\circ}\right)$ is much larger than that near the coast of the US $\left(33.36^{\circ}\right)$. After wind speeds $<6 \mathrm{~m} \mathrm{~s}^{-1}$ were removed, the RMSEs near the coasts of China and the US decreased to $41.18^{\circ}$ and $16.75^{\circ}$, respectively (Table 2 ).

\section{Discussion}

\subsection{Comparison with Other Satellite Wind Retrievals}

Many satellite missions, including altimeters, radiometers and scatterometers, can provide global wind speed and direction. To evaluate the performance of those satellite products, the wind retrievals were calibrated and validated with in situ measurements (Supplementary Material). The accuracy of satellite wind vectors depends on wind product versions, the method of validation, periods, oceans, weather conditions, the strictness of quality control and the magnitude of wind speed [5,10,11,15,25].

Using US west coast buoys, Pickett et al. [5] reported that the RMSEs of QuikSCAT wind retrievals were $1.6 \mathrm{~m} \mathrm{~s}^{-1}$ and $38^{\circ}$ after removing wind speeds less than $3 \mathrm{~m} \mathrm{~s}^{-1}$ and dropped to $1.4 \mathrm{~m} \mathrm{~s}^{-1}$ and $37^{\circ}$ after removing rain-flagged data, respectively. Similarly, WindSat wind speed RMSEs of 1.44 and $1.18 \mathrm{~m} \mathrm{~s}^{-1}$ were found on the US west and east coasts, respectively [14]. A higher RMSE of ASCAT wind speed (1.92 $\left.\mathrm{m} \mathrm{s}^{-1}\right)$ was reported along the coast of China [26]. The RMSEs of HY-2A wind speeds and directions were $2.46 \mathrm{~m} \mathrm{~s}^{-1}$ and $53.65^{\circ}$, respectively, using 39 near shore NDBC buoys [8]. Compared with the performance of ASCAT wind retrievals along the coast of China, the bias and RMSE of CFOSAT retrievals are much higher, which is mainly due to the buoys being closer to the shore. In brief, the performance of CFOSAT is comparable to that of QuickSCAT, HY-2A and ASCAT.

Most of the wind retrieval evaluation studies were conducted in offshore areas using NDBC, TAO, RAMA and PIRATA buoy observations. During July 1999-December 2000, RMSEs of QuikSCAT wind speeds of $1.01 \mathrm{~m} \mathrm{~s}^{-1}$ and directions of $29.6^{\circ}$ were obtained when all flagged data were excluded [4]. After removing rain effects, the RMSE of the QuikSCAT wind directions dropped to $20^{\circ}$ and $15^{\circ}$ when wind speeds were larger than $3 \mathrm{~m} \mathrm{~s}^{-1}$ and $6 \mathrm{~m} \mathrm{~s}^{-1}$, respectively [5]. Over a wind speed of 3-20 $\mathrm{m} \mathrm{s}^{-1}$ under rain-free conditions, the RMSE of QuikSCAT wind speed was $1.22 \mathrm{~m} \mathrm{~s}^{-1}$ and the STD of wind direction was $18.7^{\circ}$ [12]. In the Indian Ocean, the RMSEs of wind speed of $1.57 \mathrm{~m} \mathrm{~s}^{-1}$ and wind direction of $44.1^{\circ}$ were reported from 1999-2003 [6]. Large RMSEs of $1.69 \mathrm{~m} \mathrm{~s}^{-1}$ and $34.67^{\circ}$ were found over a short period from 1-21 November 2009 [27]. Overall, the RMSE of wind speed varies from $1.0-1.69 \mathrm{~m} \mathrm{~s}^{-1}$ and that of wind direction varies from $15-44.1^{\circ}$, based on different validation methods, time periods, speed ranges and production versions. As a continuation of the QuikSCAT, International Space Station Scatterometer (ISSRapidScat) showed similar performance (wind speed RMSE $=1.42 \mathrm{~m} \mathrm{~s}^{-1}$; wind direction RMSE $=19.5^{\circ}$ ) when all flagged data were excluded [28].

For ASCAT wind data, RMSEs of $0.79-1.72 \mathrm{~m} \mathrm{~s}^{-1}$ for wind speed and $16-18^{\circ}$ for wind direction were obtained over a short period of March-October 2007 [7]. The RMSEs were changed to $0.86 \mathrm{~m} \mathrm{~s}^{-1}$ and $17.97^{\circ}$ during the period of January 2012-August 2013 [29]. For the OSCAT wind product, RMSEs of $1.56 \mathrm{~m} \mathrm{~s}^{-1}$ for wind speeds and $26.69^{\circ}$ for wind directions were found in the offshore area during November 2009-June 2010 [27]. In another offshore study, the RMSEs of OSCAT wind speed and direction were $1.71 \mathrm{~m} \mathrm{~s}^{-1}$ and $51.38^{\circ}$ in the Indian Ocean and $1.92 \mathrm{~m} \mathrm{~s}^{-1}$ and $44.61^{\circ}$ in the Pacific Ocean, respectively [30]. After choosing the wind data within five times the STD, similar RMSEs of $1.54 \mathrm{~m} \mathrm{~s}^{-1}$ and $39.86^{\circ}$ were found between January 2012 and August 2013 [29]. Using the L2B product produced by the Jet Propulsion Laboratory, lower RMSEs of $1.20 \mathrm{~m} \mathrm{~s}^{-1}$ and $17.7^{\circ}$ were reported by Yang and Zhang [31] over a long period from January 2010 to February 2014. For HY-2 series products, RMSEs for HY-2A wind speeds of $1.73-1.94 \mathrm{~m} \mathrm{~s}^{-1}$ and directions of $43.11^{\circ}-$ $46.63^{\circ}$ were reported from $2012-2014$ and decreased to $1.20-1.78 \mathrm{~m} \mathrm{~s}^{-1}$ and $39.68^{\circ}-45.78^{\circ}$, respectively, after rain was excluded [9]. The RMSE of HY-2A decreased to $1.30 \mathrm{~m} \mathrm{~s}^{-1}$ and 
$27.40^{\circ}$, respectively [32]. The performance of the HY-2B wind data was better (the RMSEs of wind speed and direction were $0.98 \mathrm{~m} \mathrm{~s}^{-1}$ and 19.63 and $1.22 \mathrm{~m} \mathrm{~s}^{-1}$ and $25.69^{\circ}$ for the two algorithm products, respectively) [10].

The radiometer and altimeter wind products were also evaluated, as shown in the Supplementary Material. RMSEs of the CFOSAT wind speed of $1.32 \mathrm{~m} \mathrm{~s}^{-1}$ and direction of $33.61^{\circ}$ were obtained and the values dropped to $1.16 \mathrm{~m} \mathrm{~s}^{-1}$ and $30.41^{\circ}$, respectively, after excluding rain contamination in the offshore area (Table 1). These results are highly consistent with those of preliminary evaluation studies [17,18]. Strictly speaking, the performance comparison of different wind products is related to the method of validation, the strictness of quality control, the magnitude of wind speed and product version. In general, the performance of the CFOSAT wind data is equal to that of the QuikSCAT, ASCAT, OSCAT, HY-2A, HY-2B, ISS-RapidScat, WindSat, SSMIS series, AMSR series, Sentinel-3 and Jason-3 wind products.

\subsection{The Impact of Land and Rain Contamination on Wind Retrievals}

A number of elements, such as rain, wind variability, chaotic sea state and land/ice contamination have large impact on the quality of satellite wind retrievals [33]. The wind retrievals from CFOSAT were fully evaluated on the basis of measurements observed from 217 buoys during the first two years of the satellite.

In the near shore, RMSEs of $1.63 \mathrm{~m} \mathrm{~s}^{-1}$ for wind speeds and $36.97^{\circ}$ for directions were collected, which dropped considerably to $1.32 \mathrm{~m} \mathrm{~s}^{-1}$ and $33.61^{\circ}$ offshore. Similarly, the biases for wind speeds and directions offshore were lower than those near shore $(-0.01$ compared with $0.33 \mathrm{~m} \mathrm{~s}^{-1}$ and $1.36^{\circ}$ compared with $2.57^{\circ}$ ). Notably, this difference is due to the effect of land on radar backscattering [8]. Higher bias and RMSE in the near shore than in the offshore were also reported in the QuikSCAT and HY-2A retrievals [5,8,34]. Additionally, when the land flag was used, the RMSEs of wind speeds and directions decreased to $1.29 \mathrm{~m} \mathrm{~s}^{-1}$ and $30.81^{\circ}$, respectively. These values are close to those found in the offshore region, which indicates a good performance of the land flag.

The poorer performance on the coast of China is largely due to the buoy sites being closer to the shore than on the US coast (Table 2). Similar outcomes were obtained by comparing the HY-2A wind speeds with in situ measurements on the coast of China [26]. The researcher found that the RMSE steadily decreased from $2.31 \mathrm{~m} \mathrm{~s}^{-1}$ in the area $7 \mathrm{~km}$ away from the shore to less than $1.0 \mathrm{~m} \mathrm{~s}^{-1}$ as the buoy was farther away from the shore [24].

Raindrops have a substantial impact on scatterometer wind retrievals. In the offshore area, approximately $9 \%$ of collocations are flagged by rain, which was equal to that of approximately $10 \%$ in HY-2A $[9,32]$ and higher than that of approximately $5 \%$ in $\mathrm{HY}-2 \mathrm{~A}$, HY-2B and OSCAT2 in another study [11]. During the present study, significantly increased errors of wind speed and direction were found under rainy conditions (Figures 3 and 4 and Table 1). The error was greatly increased at all in situ wind speeds except for in situ wind speeds $>17 \mathrm{~m} \mathrm{~s}^{-1}$ (Figure 5). Similar effects of rain contamination were reported for the QuikSCAT and HY-2 scatterometers [5,9,12,35]. It should be noted that under rain effects, the RMSE is larger and $r$ is lower offshore than near the shore (Table 1). This is an interesting phenomenon that might imply an interaction between rain and land.

\subsection{Effects of Atmospheric and Oceanic Environment}

The $r$ values between the wind residuals and various buoy parameters were calculated to examine the impact factors on the CFOSAT wind retrievals (Figure 8). Although the $r$ value was very small for all parameters, the residual is significantly correlated with most parameters. 

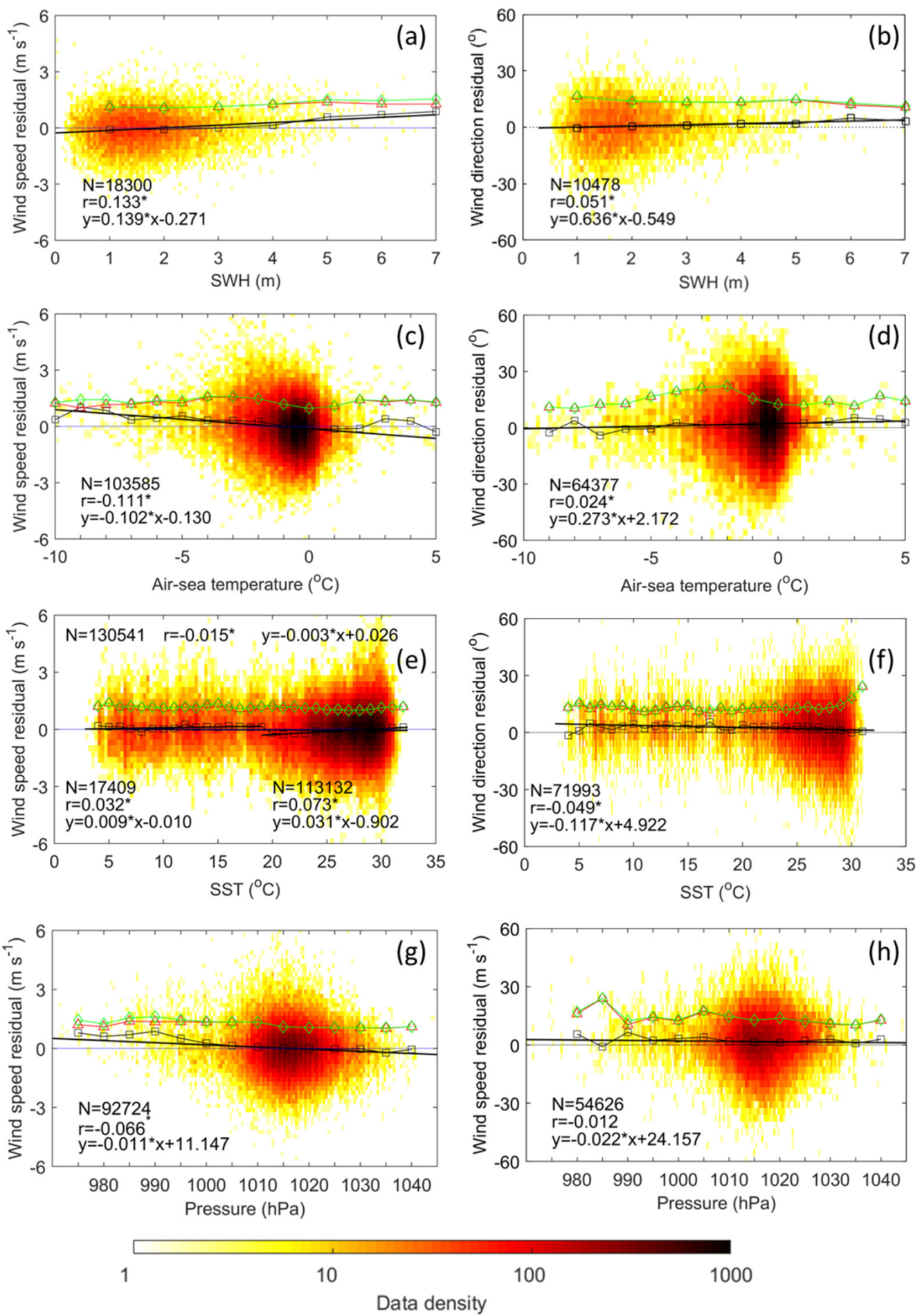

Figure 8. Scatter plots for wind speed and direction (wind speed higher than $6 \mathrm{~m} \mathrm{~s}^{-1}$ ) residuals with SWH $(\mathbf{a}, \mathbf{b})$, air-sea temperature difference $(\mathbf{c}, \mathbf{d})$, SST $(\mathbf{e}, \mathbf{f})$ and atmospheric pressure $(\mathbf{g}, \mathbf{h})$. Black squares, red triangles and green diamonds represent bias, STD and RMSE, respectively. The bold black lines indicate the least-squares linear regression. The star superscript indicates statistical significance at the $99 \%$ level.

\subsubsection{SWH}

The CFOSAT wind speed is slightly underestimated for SWHs less than $2 \mathrm{~m}$ and overestimated for SWHs greater than $3 \mathrm{~m}$ (Figure 8a). Under all conditions, the bias of wind direction was slightly overestimated and it increased as the SWH increased (Figure $8 b$ ). 
The STD and RMSE of wind speed increased slowly, while the STD and RMSE of wind direction decreased sharply as the SWH increased. The SWH was positively correlated with the wind residuals. Past findings demonstrated that SWH had a large impact on wind speed retrievals [36-38]. A positive relationship between wind speed residual and SWH was found in the scatterometer and altimeter retrievals [37-39]. After considering the effect of SWH on altimeter wind speed retrieval, RMSE and $\mathrm{r}$ were improved [38]. In conclusion, SWH can be used as a parameter to improve the CFOSAT retrievals.

\subsubsection{Air-Sea Temperature Difference}

A positive wind speed bias of more than $0.26 \mathrm{~m} \mathrm{~s}^{-1}$ for air-sea temperature differences less than $2{ }^{\circ} \mathrm{C}$ was observed (Figure 8c). A negative (positive) correlation between the airsea temperature difference and residual wind speed (direction) was observed (Figure 8d). Similar negative correlations were reported for QuikSCAT [4,6], ASCAT and Advanced Synthetic Aperture Radar (ASAR) [37,39] and jointly-calibrated altimeter data [38]. The $r$ value is slightly smaller than that in ASCAT and ASAR and higher than that in the jointly-calibrated altimeter product.

\subsubsection{SST}

There is an overestimation of wind speed $\left(0.10 \mathrm{~m} \mathrm{~s}^{-1}\right)$ for SSTs lower than $19^{\circ} \mathrm{C}$ and an underestimation of approximately $0.06 \mathrm{~m} \mathrm{~s}^{-1}$ for SSTs higher than $19^{\circ} \mathrm{C}$ (Figure 8e). A small negative correlation of -0.015 for all data was obtained, which was also reported in previous studies $[4,38,39]$. An obvious break of wind speed residuals was obtained at the bins of $19^{\circ} \mathrm{C}$. Two higher positive correlations could be observed when the data were divided into $>19^{\circ} \mathrm{C}$ and $<19^{\circ} \mathrm{C}$ parts. In the Indian Ocean, there was no substantial association between wind residuals and SSTs, which might be attributable to the small SST range $\left(24-32{ }^{\circ} \mathrm{C}\right)[6]$. The impacts of SST on the Ku-band radar backscatter can be removed using a new NSCAT-5 geophysical model function [40]. The wind direction bias was overestimated for SSTs higher than $5{ }^{\circ} \mathrm{C}$ and large RMSEs and STDs were observed at high SSTs $\left(>30^{\circ} \mathrm{C}\right)$ (Figure $\left.8 \mathrm{f}\right)$.

\subsubsection{Atmospheric Pressure}

The CFOSAT wind speed was overestimated by $0.7 \mathrm{~m} \mathrm{~s}^{-1}$ for atmospheric pressure $<1000 \mathrm{hPa}$ and slightly underestimated for atmospheric pressure $>1015 \mathrm{hPa}$ (Figure 8g). The negative correlation of -0.07 is consistent with previous studies [37,39]. The bias of wind direction was positive under all conditions and gradually decreased with increasing atmospheric pressure (Figure $8 \mathrm{~h}$ ).

\subsubsection{Ocean Currents}

The winds retrieved by scatterometers denote the wind speed relative to the ocean surface $[41,42]$. Thus, the satellite wind speed should be weaker than the in situ wind speed when the ocean surface current is in the same direction as the wind direction and should be stronger when the currents oppose the wind direction. Previous studies $[42,43]$ proved the effects of ocean surface currents on wind retrievals from the QuikSCAT scatterometer. In the Bay of Bengal, Sharma et al. [44] found that the impact of ocean currents is much greater on wind speed retrieved by altimeters (AltiKa) than on wind speed retrieved by scatterometers (ASCAT and Indian Space Research Organizations Scatterometer Mission (SCATSAT)).

To examine the effect of ocean surface currents on the CFOSAT wind retrievals, the ocean near-surface current vectors from the RAMA, PIRATA and Ocean Climate Station buoys were used to obtain collocations. A total of 6280 collocations were obtained with a spatial difference of $0.25^{\circ}$ and a time difference of $30 \mathrm{~min}$ under rain-free conditions. Previous studies assumed that only the component of the current vector in the direction of 
the wind contributed to the wind residual $[44,45]$. Therefore, the effective ocean surface current $\left(\mathrm{u}_{\mathrm{p}}\right)$ was computed as follows:

$$
\mathrm{u}_{\mathrm{p}}=\left|\mathrm{U}_{\mathrm{s}}\right| \cos \left(\theta_{\mathrm{s}}-\theta_{\text {buoy-wind }}\right)
$$

where $\left|U_{s}\right|$ is the absolute value of ocean surface currents, $\theta_{\mathrm{s}}$ is the current direction and $\theta_{\text {buoy-wind }}$ is the in situ wind direction.

A small negative correction between wind speed residuals and $u_{p}$ was obvious (Figure 9), indicating that the CFOSAT wind exceeds the in situ measurement under the condition of an opposite current. The $r$ was -0.15 , which is similar to that found by ASCAT, QuikSCAT and SCATSAT and less than that of European Remote Sensing Satellite (ERS) and AltiKa [44-46]. Under high ocean current velocity conditions $\left(>0.5 \mathrm{~m} \mathrm{~s}^{-1}\right.$, red circles in Figure 9), the value of $r$ was enhanced to -0.33 , which indicates that surface currents have a great impact on wind retrieval over strong ocean currents. The slopes were -0.94 and -0.93 . These values are similar to the slope observed by QuikSCAT [45] and lower than the slope observed by AltiKa [44]. Due to the vertical shear between the Ekman currents and the geostrophic currents, the currents measured at $12 \mathrm{~m}$ and below are different from the ocean surface currents.

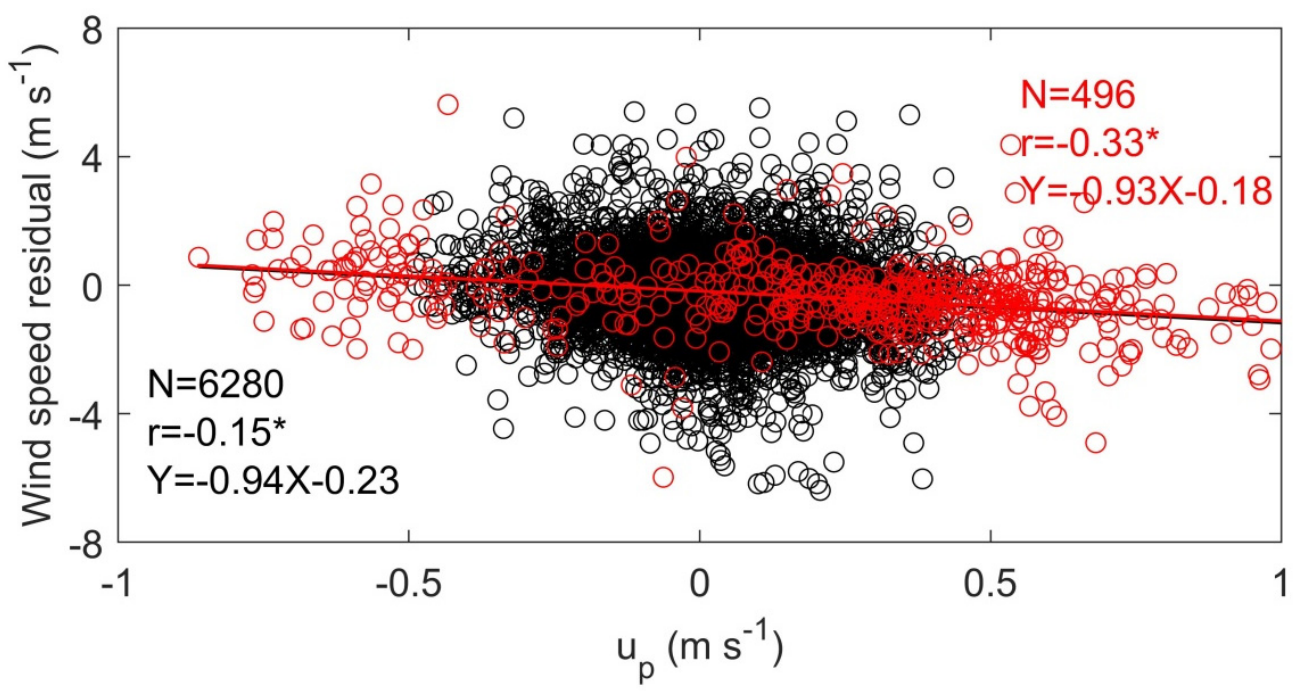

Figure 9. Scatter plot of CFOSAT wind speed differences against the effective current speed $\left(u_{p}\right)$ in all conditions (all circles) and ocean surface currents greater than $0.5 \mathrm{~m} \mathrm{~s}^{-1}$ (red circles). The star superscript denotes statistical significance at the $99 \%$ level.

\subsection{Wind Performance during the Passage of Tropical Cyclone}

Tropical cyclones (TCs) have a large impact on human lives and property. There is a strong need to measure surface wind speeds during TCs and predict TC intensities. Sea surface wind vectors retrieved by satellite scatterometers, such as QuikSCAT, RADARSAT2, ASCAT, HY-2A, HY-2B and OSCAT, have been used for TC forecasts, modeling and structure studies [47-50].

To evaluate the performance of CFOSAT wind retrievals under the passage of TCs, half hourly TC track locations from the Cooperative Institute for Meteorological Satellite Studies (http://cimss.ssec.wisc.edu/, 1 March 2021) were used to obtain collocations. Simply assuming a TC affect radius of $303 \mathrm{~km}$ (global median value of TC radius where

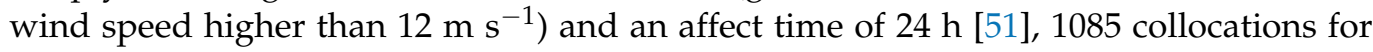
the wind speed and 994 matchups for the wind direction were obtained with a spatial difference of $0.25^{\circ}$ and a time difference of $30 \mathrm{~min}$. All collocations were located in the offshore regions. Approximately $26 \%$ of them were under rainy conditions, which was approximately three times higher than the percentage of collocations offshore under all 
weather conditions (approximately 9\%). The collocations resulted in a wind speed bias of $0.29 \mathrm{~m} \mathrm{~s}^{-1}$ and an RMSE of $2.11 \mathrm{~m} \mathrm{~s}^{-1}$ (Figure 10), which were much higher than those of $-0.01 \mathrm{~m} \mathrm{~s}^{-1}$ and $1.32 \mathrm{~m} \mathrm{~s}^{-1}$, respectively, under all weather conditions in the offshore area (Figure 2 and Table 1). One may argue that the poor performance was most likely due to rain contamination during TC passage [52]. However, the bias ( 0.20 compared with $-0.04 \mathrm{~m} \mathrm{~s}^{-1}$ ) and RMSE (1.48 compared with $1.16 \mathrm{~m} \mathrm{~s}^{-1}$ ) performances were also poor under rain-free conditions. Therefore, this might be due to the large RMSE at high wind speeds $[49,53]$ and the reduction in the maximum wind speed due to spatial averaging [52]. For wind direction, the bias was small and the RMSE decreased from $23.88^{\circ}$ under all weather conditions to $20.17^{\circ}$ after rain was excluded (Figure 10). The good performance of wind direction may be attributed to the mean wind speed of $9.39 \mathrm{~m} \mathrm{~s}^{-1}$ during TC passage being much higher than that of $6.56 \mathrm{~m} \mathrm{~s}^{-1}$ under all weather conditions because the RMSE is very small at wind speeds $>7 \mathrm{~m} \mathrm{~s}^{-1}$ (Figure 5).
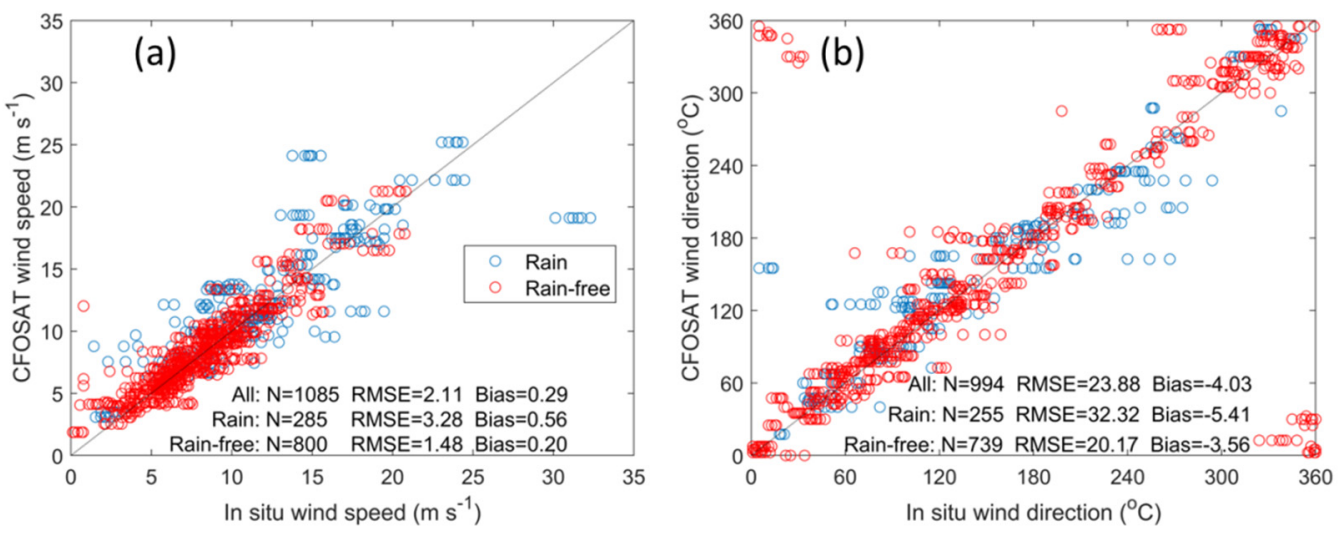

Figure 10. Scatter plots of collocations for wind speeds (a) and directions (b) under the impact of tropical cyclones.

The large wind speed RMSE during the passage of TCs is generally consistent with the findings of Chou et al. [53,54]. Although the absolute value of wind speed RMSE is less than that obtained in Chou et al. [54], the relative value (16\%) is almost equivalent to that obtained by Chou et al. [54]. Likewise, the value of wind direction RMSE is almost equivalent to that obtained by Chou et al. [54] and much lower than that obtained by Chou et al. [53]. The large RMSE for wind direction described by Chou et al. [53] was mainly due to the sampling conducted around the TC eye area.

\section{Conclusions}

This study comprehensively evaluated the CFOSAT wind retrievals from December 2018 to December 2020 by comparing them with in situ measurements from 217 buoys. Approximately 300,000 collocations were obtained within the spatial and temporal separations and were limited to less than $0.25^{\circ}$ and $30 \mathrm{~min}$. The results reveal that the overall biases and RMSEs of wind speed are $0.06 \mathrm{~m} \mathrm{~s}^{-1}$ and $1.39 \mathrm{~m} \mathrm{~s}^{-1}$ and those of wind direction are $1.61^{\circ}$ and $34.32^{\circ}$, respectively. The bias and RMSE in the near shore were increased to $0.33 \mathrm{~m} \mathrm{~s}^{-1}$ and $1.63 \mathrm{~m} \mathrm{~s}^{-1}$ for wind speed and $2.57^{\circ}$ and $36.97^{\circ}$ for wind direction, respectively. After the rain flag was used, the values changed to $0.28 \mathrm{~m} \mathrm{~s}^{-1}$ and $1.42 \mathrm{~m} \mathrm{~s}^{-1}$ and $2.67^{\circ}$ and $33.43^{\circ}$, respectively. In the offshore, the bias and RMSE were $-0.01 \mathrm{~m} \mathrm{~s}^{-1}$ and $1.32 \mathrm{~m} \mathrm{~s}^{-1}$ and $1.36^{\circ}$ and $33.61^{\circ}$ for wind speed and wind direction, respectively. Under rain-free conditions, the values decreased to $-0.04 \mathrm{~m} \mathrm{~s}^{-1}$ and $1.16 \mathrm{~m} \mathrm{~s}^{-1}$ and $1.50^{\circ}$ and $30.41^{\circ}$. In particular, the RMSE of wind directions decreased to $19.69^{\circ}$ at wind speeds greater than $4 \mathrm{~m} \mathrm{~s}^{-1}$. In summary, the performance of the CFOSAT wind retrievals is approximately equal to most commonly used wind products.

The errors in nearshore buoys were larger than those offshore and larger errors were observed along the coast of China. This reduced accuracy was primarily due to land 
contamination and the high variability of coastal winds. Similarly, rain influence resulted in low accuracy and high positive bias, suggesting that rain has a significant negative impact on the CFOSAT wind retrievals. Under rain conditions, the errors offshore are greater than those near the shore, indicating an interaction of rain and land.

The effects of atmospheric and oceanic factors on wind vectors were investigated using in situ measurements. The results showed that the accuracy of CFOSAT wind retrievals is significantly affected by the SWH, air-sea temperature difference and sea surface currents. The impacts of SST and atmospheric pressure are small. These results are consistent with those for other satellites.

During the impact of TCs, a larger bias and RMSE of wind speeds and a lower bias and RMSE of wind directions were observed. The poorer performance of wind speed is mainly due to large errors in high wind speeds and the reduction in the maximum wind speed due to spatial averaging, while the better performance of wind direction might be due to smaller errors in high wind speeds during TC passage.

In summary, the accuracies of the CFOSAT wind retrievals meet the general scatterometer mission requirements. The present study indicates that the accuracies of the CFOSAT retrieval L2B wind product are reliable enough to be used in meteorology, oceanography and climate studies in combination with other satellite products.

Supplementary Materials: The following are available online at https: / www.mdpi.com/article / 10.3390/rs13101926/s1, Table S1: The performance of different scatterometers, radiometers and altimeters satellite products compared to in situ measurements.

Author Contributions: Conceptualization, H.Y. (Haijun Ye) and S.T.; methodology, J.L. (Junmin Li) and R.Z.; investigation, W.C.; data curation, H.Y. (Haijun Ye), J.L. (Junliang Liu), B.L. and F.Z.; writing-original draft preparation, H.Y. (Haijun Ye); writing-review and editing, D.T. and S.W.; supervision, S.T.; project administration, H.Y. (Haijun Ye); funding acquisition, H.Y. (Haijun Ye), S.L., D.T. and H.Y. (Hongqiang Yang). All authors have read and agreed to the published version of the manuscript.

Funding: This research was funded by the Strategic Priority Research Program of the Chinese Academy of Sciences (XDA19060501, XDA13010103), the National Natural Science Foundation of China (41806146), the Key Special Project for Introduced Talents Team of Southern Marine Science and Engineering Guangdong Laboratory (Guangzhou) (GML2019ZD0302, 2019BT02H594, GML2019ZD0602) and the Independent Research Project Program of State Key Laboratory of Tropical Oceanography (LTOZZ2004).

Data Availability Statement: The CFOSAT data are downloaded from https:/ / osdds.nsoas.org.cn. (1 March 2021) The NDBC buoy data are obtained from https:/ / www.ndbc.noaa.gov/ (1 March 2021) TAO, PIRATA and RAMA buoy data can be downloaded from https:/ / www.pmel.noaa.gov / tao/drupal/disdel/ (1 March 2021). The collocations are available from the corresponding author by request.

Acknowledgments: We acknowledge the support of the CFOSAT team, CNES and NSOAS in providing the data. In addition, the authors thank the NDBC for providing the buoy datasets. The numerical analysis is supported by the High Performance Computing Division in the South China Sea Institute of Oceanology.

Conflicts of Interest: The authors declare no conflict of interest.

\section{References}

1. Young, I.R.; Ribal, A. Multiplatform evaluation of global trends in wind speed and wave height. Science 2019, 364, 548-552. [CrossRef] [PubMed]

2. Mears, C.A.; Smith, D.K.; Wentz, F.J. Comparison of Special Sensor Microwave Imager and buoy-measured wind speeds from 1987 to 1997. J. Geophys. Res. 2001, 106, 11719-11729. [CrossRef]

3. Zhang, L.; Shi, H.; Wang, Z.; Yu, H.; Yin, X.; Liao, Q. Comparison of Wind Speeds from Spaceborne Microwave Radiometers with In Situ Observations and ECMWF Data over the Global Ocean. Remote Sens. 2018, 10, 425. [CrossRef]

4. Ebuchi, N.; Graber, H.C.; Caruso, M.J. Evaluation of wind vectors observed by QuikSCAT/SeaWinds using ocean buoy data. J. Atmos. Ocean. Technol. 2002, 19, 2049-2062. [CrossRef] 
5. Pickett, M.H.; Tang, W.; Rosenfeld, L.K.; Wash, C.H. QuikSCAT satellite comparisons with nearshore buoy wind data off the US west coast. J. Atmos. Ocean. Technol. 2003, 20, 1869-1879. [CrossRef]

6. Satheesan, K.; Sarkar, A.; Parekh, A.; Kumar, M.R.R.; Kuroda, Y. Comparison of wind data from QuikSCAT and buoys in the Indian Ocean. Int. J. Remote Sens. 2007, 28, 2375-2382. [CrossRef]

7. Bentamy, A.; Croize-Fillon, D.; Perigaud, C. Characterization of ASCAT measurements based on buoy and QuikSCAT wind vector observations. Ocean Sci. 2008, 4, 265-274. [CrossRef]

8. Yang, X.; Liu, G.; Li, Z.; Yu, Y. Preliminary validation of ocean surface vector winds estimated from China's HY-2A scatterometer. Int. J. Remote Sens. 2014, 35, 4532-4543. [CrossRef]

9. Xing, J.; Shi, J.; Lei, Y.; Huang, X.-Y.; Liu, Z. Evaluation of HY-2A Scatterometer Wind Vectors Using Data from Buoys, ERA-Interim and ASCAT during 2012-2014. Remote Sens. 2016, 8, 390. [CrossRef]

10. Wang, H.; Zhu, J.; Lin, M.; Zhang, Y.; Chang, Y. Evaluating Chinese HY-2B HSCAT Ocean Wind Products Using Buoys and Other Scatterometers. IEEE Geosci. Remote. Sens. Lett. 2020, 17, 923-927. [CrossRef]

11. Wang, Z.; Stoffelen, A.; Zou, J.; Lin, W.; Verhoef, A.; Zhang, Y.; He, Y.; Lin, M. Validation of New Sea Surface Wind Products From Scatterometers Onboard the HY-2B and MetOp-C Satellites. IEEE Trans. Geosci. Remote Sens. 2020, 58, 4387-4394. [CrossRef]

12. Freilich, M.H.; Vanhoff, B.A. The accuracy of preliminary WindSat vector wind measurements: Comparisons with NDBC buoys and QuikSCAT. IEEE Trans. Geosci. Remote Sens. 2006, 44, 622-637. [CrossRef]

13. Wentz, F.J.; Meissner, T.; Smith, D.K. Assessment of the initial release of WindSat wind retrievals. RSS Tech. Rep. 2005, 10605, 2005.

14. Zhang, L.; Shi, H.; Yu, H.; Yi, X. WindSat satellite comparisons with nearshore buoy wind data near the U.S. west and east coasts. Acta Oceanol. Sin. 2016, 35, 50-58. [CrossRef]

15. Zhang, L.; Shi, H.; Du, H.; Zhu, E.; Zhang, Z.; Fang, X. Comparison of WindSat and buoy-measured ocean products from 2004 to 2013. Acta Oceanol. Sin. 2016, 35, 67-78. [CrossRef]

16. Yang, J.; Zhang, J.; Jia, Y.; Fan, C.; Cui, W. Validation of Sentinel-3A/3B and Jason-3 Altimeter Wind Speeds and Significant Wave Heights Using Buoy and ASCAT Data. Remote Sens. 2020, 12, 2079. [CrossRef]

17. Lin, W.; Portabella, M.; Lang, S.; Dong, X.; Xu, X.; Wang, Z.; He, Y. On the Quality of Cfosat Scatterometer Winds. In Proceedings of the IGARSS 2019-2019 IEEE International Geoscience and Remote Sensing Symposium, Yokohama, Japan, 28 July-2 August 2019; pp. 8343-8346.

18. Zhu, D.; Zhang, L.; Dong, X.; Yun, R.; Lin, W. Preliminary Calibrations of the Cfosat Scatterometer. In Proceedings of the IGARSS 2019-2019 IEEE International Geoscience and Remote Sensing Symposium, Yokohama, Japan, 28 July-2 August 2019; pp. 8347-8349.

19. Zou, J.; Wang, Z.; Lin, M. Analysis of the High-Latitude Sea Surface Wind Acquisition Ability of Seven Satellite Scatterometers. IEEE Geosci. Remote. Sens. Lett. 2021, 1545-1549. [CrossRef]

20. Lin, W.; Dong, X.; Portabella, M.; Lang, S.; He, Y.; Yun, R.; Wang, Z.; Xu, X.; Zhu, D.; Liu, J. A perspective on the performance of the CFOSAT rotating fan-beam scatterometer. IEEE Trans. Geosci. Remote Sens. 2018, 57, 627-639. [CrossRef]

21. Wang, X.; Zhang, R.; Huang, J.; Zeng, L.; Huang, F. Biases of five latent heat flux products and their impacts on mixed-layer temperature estimates in the S outh C hina S ea. J. Geophys. Res. Oceans 2017, 122, 5088-5104. [CrossRef]

22. Kara, A.B.; Wallcraft, A.J.; Bourassa, M.A. Air-sea stability effects on the $10 \mathrm{~m}$ winds over the global ocean: Evaluations of air-sea flux algorithms. J. Geophys. Res. 2008, 113. [CrossRef]

23. Peng, G.; Zhang, H.-M.; Frank, H.P.; Bidlot, J.-R.; Higaki, M.; Stevens, S.; Hankins, W.R. Evaluation of various surface wind products with OceanSITES buoy measurements. Wea. Forecast. 2013, 28, 1281-1303. [CrossRef]

24. Peixoto, J.P.; Oort, A.H. Physics of Climate. 1992. Available online: https://www.sciencedirect.com/science/article/pii/030852 1X96867722 (accessed on 1 December 2020).

25. Hwang, P.A.; Teague, W.J.; Jacobs, G.A.; Wang, D.W. A statistical comparison of wind speed, wave height, and wave period derived from satellite altimeters and ocean buoys in the Gulf of Mexico region. J. Geophys. Res. 1998, 103, 10451-10468. [CrossRef]

26. Xu, Q.; Li, Y.; Li, X.; Zhang, Z.; Cao, Y.; Cheng, Y. Impact of Ships and Ocean Fronts on Coastal Sea Surface Wind Measurements From the Advanced Scatterometer. IEEE J. Sel. Top. Appl. Earth Obs. Remote Sens. 2018, 11, 2162-2169. [CrossRef]

27. Kumar, R.; Chakraborty, A.; Parekh, A.; Sikhakolli, R.; Gohil, B.S.; Kiran Kumar, A.S. Evaluation of Oceansat-2-Derived Ocean Surface Winds Using Observations From Global Buoys and Other Scatterometers. IEEE Trans. Geosci. Remote Sens. 2013, 51, 2571-2576. [CrossRef]

28. Yang, J.; Zhang, J. Evaluation of ISS-RapidScat Wind Vectors Using Buoys and ASCAT Data. Remote Sens. 2018, 10, 648. [CrossRef]

29. Wu, Q.; Chen, G. Validation and intercomparison of HY-2A/MetOp-A/Oceansat-2 scatterometer wind products. Chin. J. Oceanol. Limn. 2015, 33, 1181-1190. [CrossRef]

30. Sudha, A.K.; Prasada Rao, C.V.K. Comparison of Oceansat-2 scatterometer winds with buoy observations over the Indian Ocean and the Pacific Ocean. Remote Sens. Lett. 2012, 4, 171-179. [CrossRef]

31. Yang, J.; Zhang, J. Comparison of Oceansat-2 Scatterometer Wind Data with Global Moored Buoys and ASCAT Observation. Adv. Meteorol. 2019, 2019. [CrossRef]

32. Zhao, K.; Zhao, C. Evaluation of HY-2A Scatterometer Ocean Surface Wind Data during 2012-2018. Remote Sens. 2019, 11, 2968. [CrossRef]

33. Lin, W.; Portabella, M.; Stoffelen, A.; Vogelzang, J.; Verhoef, A. ASCAT wind quality under high subcell wind variability conditions. J. Geophys. Res. 2015, 120, 5804-5819. [CrossRef] 
34. Yang, X.; Li, X.; Zheng, Q.; Gu, X.; Pichel, W.G.; Li, Z. Comparison of Ocean-Surface Winds Retrieved From QuikSCAT Scatterometer and Radarsat-1 SAR in Offshore Waters of the U.S. West Coast. IEEE Geosci. Remote. Sens. Lett. 2011, 8, 163-167. [CrossRef]

35. Weissman, D.E.; Bourassa, M.A.; Tongue, J. Effects of rain rate and wind magnitude on SeaWinds scatterometer wind speed errors. J. Atmos. Ocean. Technol. 2002, 19, 738-746. [CrossRef]

36. Quilfen, Y.; Chapron, B.; Collard, F.; Vandemark, D. Relationship between ERS scatterometer measurement and integrated wind and wave parameters. J. Atmos. Ocean. Technol. 2004, 21, 368-373. [CrossRef]

37. Stopa, J.E.; Mouche, A.A.; Chapron, B.; Collard, F. Sea State Impacts on Wind Speed Retrievals From C-Band Radars. IEEE J. Sel. Top. Appl. Earth Obs. Remote Sens. 2017, 10, 2147-2155. [CrossRef]

38. Jiang, H.; Zheng, H.; Mu, L. Improving Altimeter Wind Speed Retrievals Using Ocean Wave Parameters. IEEE J. Sel. Top. Appl. Earth Obs. Remote Sens. 2020, 13, 1917-1924. [CrossRef]

39. Wang, H.; Yang, J.; Zhu, J.; Ren, L.; Liu, Y.; Li, W.; Chen, C. Estimation of Significant Wave Heights from ASCAT Scatterometer Data via Deep Learning Network. Remote Sens. 2021, 13, 195. [CrossRef]

40. Wang, Z.; Stoffelen, A.; Zhao, C.; Vogelzang, J.; Verhoef, A.; Verspeek, J.; Lin, M.; Chen, G. An SST-dependent K u-band geophysical model function for R apid S cat. J. Geophys. Res. Oceans 2017, 122, 3461-3480. [CrossRef]

41. Kelly, K.A.; Dickinson, S.; McPhaden, M.J.; Johnson, G.C. Ocean currents evident in satellite wind data. Geophys. Res. Lett. 2001, 28, 2469-2472. [CrossRef]

42. Yu, L.; Jin, X. Buoy perspective of a high-resolution global ocean vector wind analysis constructed from passive radiometers and active scatterometers (1987-present). J. Geophys. Res. 2012, 117, C11013. [CrossRef]

43. Dickinson, S.; Kelly, K.A.; Caruso, M.J.; McPhaden, M.J. Comparisons between the TAO buoy and NASA scatterometer wind vectors. J. Atmos. Ocean. Technol. 2001, 18, 799-806. [CrossRef]

44. Sharma, R.; Agarwal, N.; Chakraborty, A.; Mallick, S.; Kumar, R. Assessing the Ocean Surface Current Impact on Scatterometer (C- and Ku-Bands) and Altimeter (Ka-Band) Derived Winds in the Bay of Bengal. IEEE Geosci. Remote. Sens. Lett. 2020, 1-5. [CrossRef]

45. Plagge, A.M.; Vandemark, D.; Chapron, B. Examining the impact of surface currents on satellite scatterometer and altimeter ocean winds. J. Atmos. Ocean. Technol. 2012, 29, 1776-1793. [CrossRef]

46. Quilfen, Y.; Chapron, B.; Vandemark, D. The ERS scatterometer wind measurement accuracy: Evidence of seasonal and regional biases. J. Atmos. Ocean. Technol. 2001, 18, 1684-1697. [CrossRef]

47. Stiles, B.W.; Danielson, R.E.; Poulsen, W.L.; Brennan, M.J.; Hristova-Veleva, S.; Tsae-Pyng, S.; Fore, A.G. Optimized Tropical Cyclone Winds from QuikSCAT: A Neural Network Approach. IEEE Trans. Geosci. Remote Sens. 2014, 52, 7418-7434. [CrossRef]

48. Jaiswal, N.; Kumar, P.; Kishtawal, C.M. SCATSAT-1 wind products for tropical cyclone monitoring, prediction and surface wind structure analysis. Curr. Sci. 2019, 117, 983-992. [CrossRef]

49. Zabolotskikh, E.; Mitnik, L.; Chapron, B. GCOM-W1 AMSR2 and MetOp-A ASCAT wind speeds for the extratropical cyclones over the North Atlantic. Remote Sens. Environ. 2014, 147, 89-98. [CrossRef]

50. Zhang, G.; Perrie, W.; Zhang, B.; Yang, J.; He, Y. Monitoring of tropical cyclone structures in ten years of RADARSAT-2 SAR images. Remote Sens. Environ. 2020, 236, 111449. [CrossRef]

51. Chavas, D.R.; Lin, N.; Dong, W.; Lin, Y. Observed tropical cyclone size revisited. J. Clim. 2016, 29, 2923-2939. [CrossRef]

52. Yueh, S.H.; Stiles, B.W.; Liu, W.T. QuikSCAT wind retrievals for tropical cyclones. IEEE Trans. Geosci. Remote Sens. 2003, 41, 2616-2628. [CrossRef]

53. Chou, K.-H.; Wu, C.-C.; Lin, S.-Z. Assessment of the ASCAT wind error characteristics by global dropwindsonde observations. J. Geophys. Res. 2013, 118, 9011-9021. [CrossRef]

54. Chou, K.-H.; Wu, C.-C.; Lin, P.-H.; Majumdar, S. Validation of QuikSCAT wind vectors by dropwindsonde data from Dropwindsonde Observations for Typhoon Surveillance Near the Taiwan Region (DOTSTAR). J. Geophys. Res. 2010, 115. [CrossRef] 